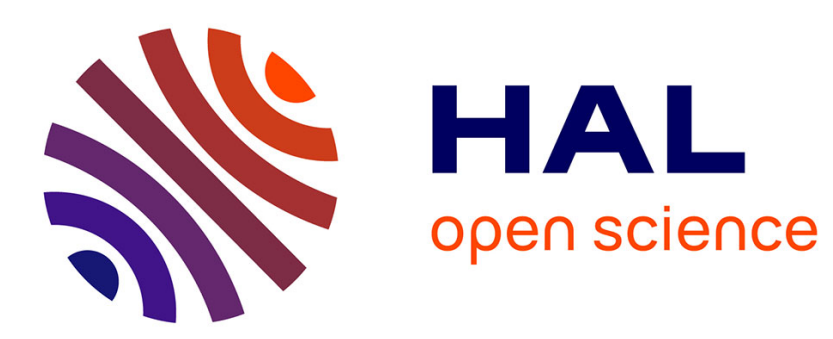

\title{
Requiem for Market Discipline and the Specter of TBTF in Japanese Banking
}

\author{
Adrian Pop, Diana Pop
}

\section{To cite this version:}

Adrian Pop, Diana Pop. Requiem for Market Discipline and the Specter of TBTF in Japanese Banking. 2009. hal-00419235

\author{
HAL Id: hal-00419235 \\ https://hal.science/hal-00419235
}

Preprint submitted on 23 Sep 2009

HAL is a multi-disciplinary open access archive for the deposit and dissemination of scientific research documents, whether they are published or not. The documents may come from teaching and research institutions in France or abroad, or from public or private research centers.
L'archive ouverte pluridisciplinaire HAL, est destinée au dépôt et à la diffusion de documents scientifiques de niveau recherche, publiés ou non, émanant des établissements d'enseignement et de recherche français ou étrangers, des laboratoires publics ou privés. 
EA 4272

\title{
Requiem for Market Discipline and the Specter of TBTF in Japanese Banking
}

\author{
Adrian POP $\left({ }^{*}\right)$ \\ Diana POP $\left(^{* *}\right)$
}

$2009 / 04$

$\left(^{*}\right)$ University of Nantes (LEMNA)

$\left.{ }^{(*)}\right)$ University of Angers (GRANEM)

INSTITUT

d'ECONOMIE et de MANAGEMENT

de NANTES - IAE
Laboratoire d'Economie et de Management Nantes-Atlantique Université de Nantes

Chemin de la Censive du Tertre - BP 52231

44322 Nantes cedex 3 - France

www.univ-nantes.fr/iemn-iae/recherche

Tél. +33 (0)2 40141719 - Fax +33 (0)2 40141749 


\title{
Requiem for Market Discipline and the Specter of TBTF in Japanese Banking
}

\author{
Adrian Pop ${ }^{1}$ \\ University of Nantes (LEMNA) \\ and \\ Diana Pop $^{2}$ \\ University of Angers (GRANEM) \\ Quarterly Review of Economics and Finance (forthcoming)
}

\begin{abstract}
This study examines the reaction of private market participants to the enhancement of the "Too-Big-To-Fail" (TBTF) doctrine in the Japanese banking sector. The event justifying the use of the "TBTF" label occurred on May $17^{\text {th }}$, 2003, when the Japanese government decided to bailout Resona Holdings, the $5^{\text {th }}$ largest financial group in the country. By using a sample of all Japanese listed banks and the standard event study methodology, we document significant and positive wealth effects in the stock market accruing to large banks and negative (though non-significant) effects accruing to smaller banks. Besides the effect on bank equity values, we also document a significant abnormal volume of trading on days following the bailout announcement date for the largest banks only. We extend our empirical analysis on stock prices and trading volumes by detecting an original "pure" risk effect in the Credit Default Swap (CDS) market.

Keywords: Too-Big-To-Fail; Market discipline; Credit default swap; Event study
\end{abstract} JEL Codes: G21; G28; G14

\footnotetext{
${ }^{1}$ Institute of Banking \& Finance, University of Nantes (LEMNA), Chemin de la Censive du Tertre, BP 52231, 44322 Nantes, Cedex 3, France, Tel.: +33-2-40-14-16-54; fax: +33-2-40-14-1650. E-mail: adrian.pop@univ-nantes.fr

${ }^{2}$ University of Angers (GRANEM), Department of Law, Economics, and Management, 13 Allée François Mitterrand, BP 13633, 49036 Angers Cedex 01, France, Tel.: +33-2-41-96-21-73; fax: +33-2-41-96-21-96. E-mail: diana.pop@univ-angers.fr

Acknowledgements

We are grateful to Akira Yoshieda (Japan Credit Rating Agency), Selina Tollworthy (Standard \&3 Poor's), and Steven Kurtosi (Moody's Investors Service) for help with data on credit ratings; Margareta Petrovan-Boiarciuc for valuable Matlab computational assistance; Hadi Salehi Esfahani (the Editor), Max Hall, Paul Hamalainen, Jean-Paul Pollin, Kazunori Suzuki, Toyoharu Takahashi, two anonymous referees, participants at the $83^{\text {rd }}$ annual conference of the Western Economic Association International (WAEI) / International Banking, Economics, and Finance Association (IBEFA), 2008 Asian Finance Association (AsianFA) / Nippon Finance Association (NFA) international conference, 2008 Financial Management Association European conference, $56^{\text {th }}$ annual meetings of the French Economics Association (AFSE), and seminar participants at the $3^{\text {rd }}$ Workshop on Bankruptcy Codes and Procedures (University of Paris X), Sorbonne Graduate Business School (GREGOR), University of Paris I - Pantheon Sorbonne (TEAM), and University of Nantes (LEMNA) for their useful comments. We are also grateful to MarkIT Group $L t d$. for making data on Credit Default Swap (CDS) contracts available to us and to Tokyo Stock Exchange (TSE) officials for providing us detailed information on the price stabilization mechanism. This research project was undertaken while Diana Pop was Associate Professor at the Sorbonne Graduate Business School (IAE de Paris). The usual disclaimer applies.
} 


\section{Introduction}

The "Too-Big-To-Fail" (TBTF) doctrine is an old but still actual topic in banking and a matter of great concern to bank regulators and supervisors around the world. From an historical perspective, the genesis of the TBTF doctrine is closely related to the Continental Illinois crisis of September 1984, when the nation's seventh largest bank was bailed out by the US government. The uninsured depositors and other creditors of both the bank and its financial parent were completely protected against the risk of loss and, at least initially, the shareholders were not wiped out. C.T. Conover, the Comptroller of the Currency at the time defended the use of public funds in the resolution process by acknowledging that the US regulators would be unable to let the largest banks in the country fail. His statement was perceived in the banking community as a clear confirmation that large (TBTF) banks will receive an inherently different treatment than smaller ones in case of financial distress. ${ }^{1}$

Besides the fairness considerations implicit in any TBTF-type policy, the critics of TBTF have argued that the doctrine is likely to exacerbate the moral hazard problem for the biggest banks by weakening the incentives of large and sophisticated creditors and other private counterparts to monitor risk taking behavior and impose market discipline on these banks. $^{2}$ On the other hand, the policy of TBTF has been defended in most cases by invoking systemic risk-based arguments. Specifically, bank regulators have always expressed fears that the failure of a large, systemically important bank, with a strong retail deposit network and broad interconnections in the interbanking market and payment system, would have serious negative consequences on other banks and the financial system as a whole. ${ }^{3}$

There is a broad consensus among many observers that the term "TBTF" is a somewhat misleading sobriquet. In one sense, troubled TBTF banks might, in fact, "fail": their charters are often revoked by the regulators, managers are usually forced to resign, and the old shareholders lose part or all of their initial investments. The definition of TBTF is further complicated by the fact that the government may decide to rescue even small banks, especially if the financial system is likely to be affected by a generalized, systemic crisis. In addition, in some countries (e.g. France, Italy, and Germany) the use of taxpayers' funds to bail out state-owned banks cannot be seen as a strict application of the TBTF doctrine. ${ }^{4}$

\footnotetext{
${ }^{1}$ For an excellent discussion of the history of the TBTF doctrine in the US, its economic consequences, and the controversy around its adoption, the reader can refer to Kaufman (2002). Stern and Feldman (2004) provide a comprehensive analysis of the TBTF problem and critically examine several policy recommendations to cope with its negative economic effects. Also see Pollin (2005) for an interesting discussion of the key dilemmas faced by bank regulators when considering the application of the TBTF doctrine.

${ }^{2}$ In their book, Stern and Feldman (2004) also mention the resource misallocation problem arising under a TBTF regime. To be more precise, a bank that is more likely to be bailed out may not have incentives to innovate and will most probably operate in a cost-inefficient manner. Moreover, as the stakeholders of TBTF banks are fully protected in case of failure, they have no incentives to put the inefficient banks out of business.

${ }^{3}$ De Bandt and Hartmann (2002) is one of the rare references that explains in great detail the various transmission channels of systemic risk in banking and financial markets.

${ }^{4}$ For instance, the bailout of Crédit Lyonnais at the beginning of the nineties, which cost French taxpayers about $\$ 75$ billion, is certainly not an example of the regulatory use of TBTF even if the troubled bank was
} 
Nowadays, "TBTF" has become a taboo acronym among bank regulators and supervisors. In the vast majority of industrialized countries, the high-ranking officials rarely recognize that a large financial institution under their watch is "too big to fail." For instance, the enactment of the FDIC Improvement Act (FDICIA) at the beginning of 1990 was a clear signal that the US Congress intended to substantially reduce, if not eliminate, the practice of the TBTF doctrine (see Wall, 1993, for a careful analysis of FDICIA's provisions in the context of TBTF). ${ }^{5}$ However, according to Stern and Feldman (2004), TBTF remains a serious problem because FDICIA has a systemic risk exception: a bank could be declared TBTF and rescued from failure if not doing so would have dramatic consequences on the economy. ${ }^{6}$ In the same vein, Flannery (2007) notes that, given the importance of credible procedures for closing large, complex financial firms, the issue of TBTF (or "too big to re-organize quickly") should have a prominent place on the future research agenda on safe and soundness banking regulation. ${ }^{7}$

Empirical studies on TBTF not related to the Continental Illinois crisis are quite rare, in part because of the absence of clear TBTF episodes during the recent history of banking crises (see BIS, 2004, for an extensive review). However, a noteworthy event that was likely to significantly influence investors' expectations of receiving TBTF protection occurred in Japan, on May $17^{\text {th }}$, 2003, when the government authorities decided to bailout Resona Holdings, the $5^{\text {th }}$ largest financial group in the country. As a result of unexpectedly large losses, the capital adequacy ratio of the group fell dangerously low to $3.8 \%$ and that of Resona Bank, its main wholly-owned subsidiary, to just $2.1 \%$. The losses basically reflected increasingly stringent auditor evaluations of the tangibility of the deferred tax assets (DTA) and their quality as "Tier 1" regulatory capital. ${ }^{8}$ As the option to raise private capital in the financial markets was not feasible, Resona had to seek financial support from the government. After the emergency meeting of the Financial System Management Council on May $17^{\text {th }}$, Prime Minister Koizumi decided to boost the bank's capital ratio to over $12 \%$ by using public funds in order "to maintain a smooth functioning of financial markets

one of the largest financial institutions in France at the time. In this case, the bank received public funds simply because the French government was its main shareholder (see also Pollin, 2005).

${ }^{5}$ In a recent article published in the Wall Street Journal, Berman (2007) quotes Julapa Jagtiani, a Federal Reserve economist, who cautions that nowadays, "at the Fed, we don't have a list of Too Big To Fail banks."

${ }^{6}$ The exception may be invoked only with the agreement of a two-thirds majority of the Board of Directors of the FDIC, a two-thirds majority of the Board of Directors of the Fed, and the Secretary of the Treasury (after consultation with the President). See Kaufman (2002) and Mishkin (2006) for more favorable views on the role of FDICIA in reducing the TBTF expectations.

${ }^{7}$ Bliss (2003) provides a detailed discussion of the plethora of bankruptcy procedures, potential incoherencies and ambiguities characterizing the failure resolution process for "large complex financial organizations" (LCFOs), these opaque, highly-sophisticated, giants dominating the modern financial landscape.

${ }^{8}$ DTA consist of net operating losses carried forward, as well as temporary differences between financial accounting and tax computations arising primarily from loan loss provisions, unrealized losses on investment portfolios, provisions for pension liabilities, and depreciation. DTA have value only if the bank is able to regain profitability in the near future. As the tax authority usually does not reimburse the DTA if the bank goes bankrupt, their quality as regulatory capital is quite doubtful. See Fukao (2003) and Skinner (2006) for additional details on the deferred tax accounting in Japan. 
in Japan and in local areas" and "to prevent a financial setback from developing into a breakdown of the nation's entire economy." A few weeks later, on June $10^{\text {th }}$, the Deposit Insurance Corporation agreed to purchase $¥ 296$ billion ordinary shares and $¥ 1,663$ billion voting convertible preference shares in Resona Bank. These securities were exchanged for shares in Resona Holdings on August $7^{\text {th }}$ giving the government $68.3 \%$ of the voting rights in the company. The injection of public funds measured around $¥ 2$ trillion (about $\$ 17$ billion) or nearly $8 \%$ of the group's consolidated assets. The claims of all depositors (irrespective of their size) and other uninsured creditors were fully protected against the risk of loss and, most surprisingly, the protection has been extended even to Resona's shareholders. ${ }^{9}$

The main objective of the present study is to use Resona's bailout - an exceptional event per se - as a natural experiment to examine the reaction of private market participants (bank shareholders and large counterparties in credit derivative transactions) to the enhancement of the TBTF doctrine in the Japanese banking sector. We also discuss the relevance of our empirical findings to recent proposals for reinforcing bank market discipline in Japan. Before describing the methodology and the main results of our analysis, let us review the previous empirical studies on the issue at hand and explain how the present paper contributes to the existing literature.

In order to assess the existence and scope of TBTF protection, some previous studies attempted to determine the extent to which financial markets reflect the subsidy provided by governmental guarantees to banks considered "too big to fail." Providing an extensive review of these studies, which are almost all concentrated on the US banking sector, is beyond our purpose. ${ }^{10}$ Rather, in what follows we decided to only briefly resume the main empirical results of these studies and then focus our literature review on the Japanese evidence.

The key findings from the empirical literature on TBTF effects can be summarized as follows:

- using the standard event study methodology, some authors (e.g. O'Hara and Shaw, 1990, Swary, 1986) show that after the Continental Illinois bailout announcement, the largest US banks experienced significantly positive abnormal returns in the stock market;

- the analysis of bank merger activity also confirms the existence of TBTF expectations: only mergers undertaken by the largest banks result in an increase in market value for shareholders (see e.g. Kane, 2000, Penas and Unal, 2001) and banking organizations are willing to pay an estimated $\$ 14$ to $\$ 16.5$ billion extra premium for mergers that enable them to attain TBTF status (see Brewer and Jagtiani, 2007);

- in addition, the TBTF effects are detectable in the prices and quantities of uninsured liabilities in the primary and secondary bank debt markets (see e.g. Flannery and

\footnotetext{
${ }^{9}$ Asiamoney, one of the leading financial magazines in the region, awarded the Resona bailout "Restructuring Deal of the Year 2003" because "the recapitalization of the bank proved to investors that the Koizumi-led government would not allow its largest financial institutions to fail."

${ }^{10}$ See Stern and Feldman (2004, chapter 4) for a comprehensive survey of this vast empirical literature.
} 
Sorescu, 1996, Billet et al., 1998, Jagtiani and Lemieux, 2000, Morgan and Stiroh, 2005): ( $i$ ) the largest banks have a lower financing cost than their risk profile would imply; (ii) the spread-risk relationship is significantly flatter for the potential TBTF candidates; and ( $i i i$ ) after a material increase in the risk profile, the funding managers of large banking organizations attempt to avoid market discipline by substantially increasing their use of insured deposits at the expense of uninsured liabilities;

- finally, rating agencies appear to be "softener" with the largest bank issuers: the largest international banks get a rating "bonus" of several notches, suggesting that TBTF beliefs may play a significant role in the assignment of credit ratings (see Rime, 2005).

The empirical literature on the presence of TBTF-type guarantees in the Japanese banking sector is quite thin, compared with the US evidence. In their analysis of the evolution of the Japanese banking crisis in the context of TBTF, van Rixtel et al. (2003) describe the frequent shifts in the regulatory actions taken by banking authorities since the beginning of the nineties as "supervisory ad-hoc pragmatism." The term designates a flexible public policy response to the banking crisis that consists of a sequence of the use of TBTF elements followed by temporary relaxations of the TBTF mentality. Sometimes, the government was unwilling to accept the collapse of the country's largest banks and injected public funds into this privileged population of banks, while smaller financial institutions were allowed to fail. At other times, in order to restore the confidence in the banking sector, Japanese authorities adopted a stricter regulatory approach and let some troubled large financial institutions fail. For instance, the Long-Term Credit Bank of Japan and Nippon Credit Bank, two large commercial banks, were allowed to go bankrupt and were effectively nationalized at the end of 1998. As the old shareholders of these banks were ousted, the government sent a clear signal to financial markets that may have been altered investors' perception regarding the use of the TBTF doctrine in Japan. By examining the impact of these failures on the stock prices of the surviving banks, Brewer et al. (2003) provide strong evidence that the contagion effect to other financial institutions was rational and information-based. Thus, they conclude that stock market signals can be used by regulators and supervisors as an indirect tool for disciplining banks. ${ }^{11}$

The presence of information-based contagion effects of bank failures in Japanese equity markets is also confirmed by Spiegel and Yamori (2004). In addition, the authors show that the TBTF coverage diminished over their sample period (1994-1999) and that the significant changes in the regulatory framework were well understood by investors and priced in the stock market. By examining the Japanese deposit market, Imai (2006) provides evidence that the deposit insurance reform of April 2002 strengthened depositor discipline by raising

\footnotetext{
${ }^{11}$ Bremer and Pettway (2002) also find empirical evidence supporting the view that the monitoring of private market actors efficiently translates into informative prices in the bank stock market. They also conclude that this result is consistent with stock market producing useful early-warning signals that could supplement regulatory discipline.
} 
the risk-sensitivity of both interest rates and deposit quantities. However, the positive effects of the reform on funding costs are significantly lower for the largest Japanese banks, which also attract more deposits than smaller banks. These results are consistent with the enhancement of the TBTF doctrine in Japan after the deposit insurance reform. The empirical findings reported by Spiegel and Yamori (2004) and Imai (2006) are in line with the notion of "supervisory ad-hoc pragmatism" proposed by van Rixten et al. (2003).

Of the few empirical studies on TBTF in Japan, only Yamori and Kobayashi (2007) study the Resona episode and its impact on the stock market, but they focus their analysis primarily on the role of deferred tax assets and auditing firms. An empirical result highly relevant to our paper is that, at least initially, large banks' shareholders did not perceive the public fund injection as a TBTF policy. However, they rationally revised their evaluation of the bailout a couple of days later, after public authorities disclosed additional information about the restructuring plan. We confirm the TBTF result reported by Yamori and Kobayashi (2007) and extend it in several important ways.

First, using a sample of all Japanese listed banks, we draw preliminary inferences about the existence of TBTF status from the very peculiarities of the Tokyo Stock Exchange (TSE). According to official presentation documents, TSE has some unique microstructure features compared with other stock markets: $(i)$ it is a pure order-driven market without specialists or market makers to regulate the price formation alchemy; $(i i)$ it is a singleprice, transaction-based continuous auction market; and (iii) it sets daily price limits for each stock to prevent wild fluctuations in prices. Specifically, we are interested in cases where bank stock prices reached (or were close to reach) their maximum allowable limits and order flow imbalances occurred on days surrounding the bailout announcement date.

Second, using the conventional event study methodology, we document significant and positive wealth effects in the stock market accruing to large banks and negative (though non-significant) effects accruing to smaller banks. Besides the effect on bank equity values, we also document a significant abnormal volume of trading on days following the bailout announcement date for the largest banks only. These findings are consistent with the enhancement of the TBTF doctrine in Japan after the announcement of Resona's bailout.

Finally, we extend our empirical analysis on stock prices and trading volumes by detecting an original "pure" risk effect in the Credit Default Swap (CDS) market. Our choice to study the CDS market reaction to the bailout announcement is quite natural. In Japan, single-name CDS is by far the most traded credit derivative contract, accounting in 2003 for approximately $95 \%$ of the market. To our knowledge, there is no empirical evidence up to date revealing the existence of TBTF-type effects in the fast-growing market for credit derivatives. This may be partially due to data availability problems characterizing a newly created market. Indeed, earlier work on CDS pricing is mostly theoretical in nature, the thin empirical literature being focused on the market reaction to changes in credit ratings and on the determinants of the CDS spreads.

The rest of the paper is organized as follows. Section 2 presents the research methodology and Section 3 describes the data sources used in our study, as well as the sampling 
procedure. The main results concerning the market's reaction to the bailout announcement are presented in Section 4. Finally, Section 5 concludes and discusses some policy implications.

\section{Methodology}

In order to determine whether Resona's bailout had a significant impact on the behavior of private market participants, we employ relatively standard event study techniques. This section briefly describes the methodology used in our empirical analysis, conducted in three major steps. First, we examine the stock market prices in order to infer whether listed banks exhibit abnormal stock returns during the period following the decision made by the Japanese government to rescue Resona Holdings. Second, as a robustness check, we use a modified form of the market model to detect abnormal trading volume on days surrounding the Resona crisis. Third, we also examine the universe of all Japanese financials obligors actively traded on the credit derivatives market in order to detect significant "jumps," if any, in CDS prices.

\subsection{Measurement of abnormal returns}

Following the previous empirical literature, we define the abnormal return for bank security $i$ on event day $t, A R_{i t}$, as the difference between actual returns $R_{i t}$ and the returns predicted by the one-factor market model, $\mathbf{E}\left[R_{i t} \mid \Phi_{t}\right]$, where $\Phi_{t}=\left\{R_{m t}\right\}$ and $R_{m t}$ is the Japanese market index (TOPIX) for day $t:^{12}$

$$
A R_{i t}=R_{i t}-\mathbf{E}\left[R_{i t} \mid \Phi_{t}\right]
$$

where $\mathbf{E}\left[R_{i t} \mid \Phi_{t}\right]=\widehat{\alpha}_{i}+\widehat{\beta}_{i} R_{m t}$. The market model parameters, $\widehat{\alpha}_{i}$ and $\widehat{\beta}_{i}$, are estimated by regressing the daily (log-differenced) stock return for the relevant bank security, $R_{i t}$, upon the corresponding broad market return, $R_{m t}$, using ordinary least squares. The market model was estimated over a 250-day "estimation window" beginning $t=-260$ through $t=-11 .{ }^{13}$ We define the "event day" as $t=0$ and a time frame of 10 days on either side of the announcement date as the "event window." The information about the decision made by the Japanese government to intervene in the management of the Resona crisis was disclosed on Friday, May $17^{\text {th }}$, after the stock market has been closed. Consequently, it is reasonable to consider May $19^{\text {th }}, 2003$ (i.e. the next business day) as the "event day" $t=0$. We expect that any stock price adjustments would take place primarily on the following trading days.

\footnotetext{
${ }^{12}$ In order to account for the interest rate sensitivity of bank returns, we also conducted the event study using a two-factor market model including both market returns and interest rates, i.e. $\Phi_{t}=\left\{R_{m t} ; Y_{t}\right\}$, where $Y_{t}$ is the daily yield on the ten-year Japanese government bond. As all of the tests yield qualitatively similar results, we present only those obtained by using the single-factor model.

${ }^{13}$ We also estimated the market model parameters using a shorter estimation window: 150-trading-day period prior to the event window. The results are similar to those reported from the 250-day estimation window.
} 
The issue of which banking organizations are covered by the TBTF policy is crucial to our analysis. After the government's emergency meeting on Saturday, May $17^{\text {th }}, 2003$, the top bank regulator, Heizo Takenaka, minister of financial services, indicated at a press conference a plan to accelerate Resona's restructuring process while keeping the bank publicly listed. In their subsequent statements, the high-ranking Japanese officials tried to convince the public that the situation at Resona was unique and that no other mega-banks needed financial support. However, as reported in the press at that time, this message was received in the financial community with both scathing criticism and guarded skepticism. Particularly, some market analysts expressed their concerns that Japan's four largest banks could also require government support to stay in business if their accounts were subjected to the same scrutiny as Resona's.

Consequently, to refine our analysis, we focus on five distinct sets of banking organizations: $\left(1^{\circ}\right)$ all the selected banks included in our final sample ("full sample", $N_{1}=93$ banks); $\left(2^{\circ}\right)$ the Top5 financial groups at the time the decision to bail out was publicly announced, viz. Mitsubishi Tokyo Financial Group - MTFG, Mizuho Financial Group - MFG, Resona Holdings - Resona, Sumitomo Mitsui Financial Group - SMFG, and UFJ Holdings - UFJ ("TBTF1" sample, $N_{2}=5$ banks); $\left(3^{\circ}\right)$ all other banks included in the full sample but not in the TBTF1 sample ("Non-TBTF1" sample, $N_{3}=88$ banks); $\left(4^{\circ}\right)$ all money center banks, viz. Mitsui Trust Holdings - MTH, Mizuho Trust \& Banking - MTB, Sumitomo Trust 8 Banking Company - STBC, and the five TBTF1 banks ("TBTF2" sample, $N_{4}=8$ banks); $\left(5^{\circ}\right)$ all banks except the eight TBTF2 banks ("Non-TBTF2" sample, $N_{5}=85$ banks).

\section{$\{$ Table 1$\}$}

Since all firms in our sample come from the same industry and share common event dates, we have to adjust the statistical tests to avoid the misspecification problems due to extreme clustering. Indeed, failure to take into account the cross-sectional dependence might induce a systematic underestimation of the standard deviation of the mean abnormal returns, implying that the standardized test statistic is no longer applicable. For that reason, we use a test statistic recommended by Brown and Warner (1985) and also used by O'Hara and Shaw (1990), which is free of cross-sectional dependence in the security-specific excess returns. ${ }^{14}$ For any given day $t$, the test statistic is defined as:

$$
\frac{\overline{A R}_{t}}{\widehat{s}\left(\overline{A R}_{t}\right)}
$$

\footnotetext{
${ }^{14}$ An alternative solution would have been to adopt a portfolio approach as in Wall and Peterson (1990) or to combine the individual firms into a Seemingly Unrelated Regressions framework. The later approach was used inter alia by Brewer et al. (2003). Note that the empirical methodology used in our study differs from the market-adjusted return model used by Yamori and Kobayashi (2007). The later model can be viewed as an approximation to the market model where $\alpha_{i}=0$ and $\beta_{i}=1$ for all firms. Although $\widehat{\alpha}_{i}$ is usually small and the average $\widehat{\beta}_{i}$ over all Japanese listed banks is close to unity, the assumption that $\beta_{i}=1$ is strongly rejected for the largest banks included in our TBTF samples (see Table 1).
} 
where $\overline{A R}_{t}=\left(1 / N_{j}\right) \sum_{i=1}^{N_{j}} A R_{i t}$ is the average daily abnormal return across sample banks, $N_{j}$ is the number of banks in the sample $j, \widehat{s}\left(\overline{A R}_{t}\right)=\left[\sum_{t=-260}^{-11}\left(\overline{A R}_{t}-\overline{\overline{A R}}\right)^{2} /(250-1)\right]^{1 / 2}$ is an estimator of the standard deviation on day $t$ based on the residual returns in the estimation period, and $\overline{\overline{A R}}=(1 / 250) \sum_{t=-260}^{-11} \overline{A R}_{t}$. It is worth noting that by using a time-series of average abnormal returns, the test statistic as defined supra is free of any potential bias induced by the cross-correlation of security returns in the event period.

Since the market-model parameters were estimated over the estimation period, the abnormal returns are in fact prediction errors. Consequently, the standard deviation estimator used in the definition of the test statistic is appropriately adjusted in order not to overstate the significance levels. The correction factor is defined as follows:

$$
k_{t}=\left\{1+(1 / 250)\left[1+\left(R_{m t}-\bar{R}_{m}\right)^{2} / \sigma_{R_{m}}^{2}\right]\right\}
$$

where $\bar{R}_{m}$ and $\sigma_{R_{m}}^{2}$ are the mean and variance of the market return in the estimation window. The standard error of the forecast is simply calculated by multiplying the estimator of the standard deviation on day $t$ by the correction factor.

The test statistic described above can be easily adjusted to investigate the significance of the average abnormal returns aggregated over the event window. For any interval $\left[\tau_{1} ; \tau_{2}\right]$ in the $[-10 ;+10]$ event window, the test statistic is defined as:

$$
\overline{C A R}\left[\tau_{1} ; \tau_{2}\right] /\left[\sum_{t=\tau_{1}}^{\tau_{2}} \widehat{s}^{2}\left(\overline{A R}_{t}\right)\right]^{1 / 2}
$$

where $\overline{C A R}\left[\tau_{1} ; \tau_{2}\right]=\sum_{t=\tau_{1}}^{\tau_{2}} \overline{A R}_{t}$ is the cumulative average abnormal return. As in the previous case, we use the correction factor $k_{t}$ to capture the idea that the market-model parameters are subject to estimation errors.

In order to check the robustness of the results we also perform two nonparametric tests based on ranks: Corrado's (1989) test for detecting the abnormal changes on a single day of the event period and Cowan's (1992) test in order to reveal the abnormal returns over multiday event periods. The advantage of the nonparametric statistical procedures is that they are not sensitive to outliers and do not require the normality assumption to achieve proper specification under the null hypothesis. We begin by transforming each bank's abnormal returns into ranks, $k_{i t}=\operatorname{rank}\left\{A R_{i t}, t \in[-260 ;+10]\right\}$, over the combined period (estimation and event window). Rank 1 designates the lower abnormal return and rank 271, the largest one. Corrado's (1989) statistic is defined as the ratio of the mean deviation of the banks' day $\tau$ rank to an estimator of the standard deviation of the mean abnormal rank using data from the combined window:

$$
\frac{\left(1 / N_{j}\right) \sum_{i=1}^{N_{j}}\left(k_{i \tau}-\mathbf{E}\left[k_{i}\right]\right)}{\widehat{s}(k)}
$$

where $\mathbf{E}\left[k_{i}\right]=1 / 2\left(T_{i}+1\right)$ is the expected rank for bank security $i, T_{i}$ is the number of nonmissing trading days in the combined window, and $\widehat{s}(k)$ is estimated as follows: 


$$
\widehat{s}(k)=\left\{(1 / 271) \sum_{t=-260}^{+10}\left[\left(1 / N_{j}\right) \sum_{i=1}^{N_{j}}\left(k_{i t}-\mathbf{E}\left[k_{i}\right]\right)\right]^{2}\right\}^{1 / 2}
$$

For event windows composed of days $\tau_{1}$ through $\tau_{2}$, Cowan's (1992) statistic is defined as:

$$
\frac{\sum_{t=\tau_{1}}^{\tau_{2}} \bar{k}_{t}-\mathbf{E}\left[k_{i}\right]}{\left[\sum_{t=-260}^{+10}\left(\bar{k}_{t}-\mathbf{E}\left[k_{i}\right]\right)^{2} / T\right]^{1 / 2}} \times \sqrt{\tau_{2}-\tau_{1}}
$$

where $\bar{k}_{t}$ is the average rank across the $N_{j}$ bank securities on day $t$.

\subsection{The abnormal trading volume metric}

To check for the robustness of our results, we also perform an empirical analysis in terms of unexpected or abnormal volumes of trading. As there are no theoretical foundations for modeling the expected trading volume, we use a log-form of the market model that is close to that employed by Swary (1986). ${ }^{15}$ Our trading volume metric is the fraction of the number of outstanding shares $N O S H_{i t}$ that is traded on a given day $t$ over the $[-260 ;+10]$ window:

$$
\Psi_{i t}=\frac{V_{i t}}{N O S H_{i t}} \times 100
$$

where $V_{i t}$ is the number of bank $i$ shares traded on day $t$. As recommended in previous studies (see e.g. Campbell and Wasley, 1996, and references therein), we use a log-transformation of the percentage of the number of outstanding shares traded: $\vartheta_{i t}=\ln \left(\Psi_{i t}+0.000255\right)$. The small constant of 0.000255 is added to avoid exceptional cases were there was no trading volume on some days.

We define the abnormal volume of trading for bank security $i$ on event day $t, A V_{i t}$, as the difference between actual trading volume $\vartheta_{i t}$ and the expected volume $\mathbf{E}\left[\vartheta_{i t} \mid \Phi_{t}\right]$ :

$$
A V_{i t}=\vartheta_{i t}-\mathbf{E}\left[\vartheta_{i t} \mid \Phi_{t}\right]
$$

In this case, $\Phi_{t}=\left\{\Psi_{m t}\right\}$, where $\Psi_{m t}$ is the market volume measure for a given day $t$, computed as follows:

$$
\Psi_{m t}=\frac{\sum_{i=1}^{M} V_{i t}}{\sum_{i=1}^{M} N O S H_{i t}} \times 100
$$

$M$ designates the number of securities in the Japanese broad market index, TOPIX. The expected trading volume is defined as $\mathbf{E}\left[\vartheta_{i t} \mid \Phi_{t}\right]=\widehat{\lambda}_{i}+\widehat{\gamma}_{i} \vartheta_{m t}$, where $\vartheta_{m t}=\ln \left(\Psi_{m t}\right)$ and $\widehat{\lambda}_{i}$, $\widehat{\gamma}_{i}$ are estimated over the same 250-day estimation window by using ordinary least squares.

\footnotetext{
${ }^{15}$ In an alternative specification, we also used each bank's median trading volume calculated over the estimation period as a proxy for the expected volume. In this case, the median-adjusted abnormal volume of trading is defined as the difference between the observed turnover ratio and the median turnover ratio through the estimation window $[-260 ;-11]$. Since all of the results are virtually the same, we only report results obtained from the modified market model abnormal trading volume.
} 
As far as the statistical procedures are concerned, the parametric and nonparametric tests are constructed in an analogous manner to the previous case of abnormal returns.

\subsection{Abnormal CDS spread levels and changes}

To examine empirically whether the decision to bail out the $5^{\text {th }}$ banking organization in Japan has a "pure" risk effect on other Japanese financial obligors actively traded on the credit derivatives market, we use two straightforward statistical procedures: $(i)$ a classical mean test and (ii) a constant mean model. In the first case, our conjecture is that the mean of changes in CDS prices is lower than zero on days following the announcement date, indicating a significant change in the market's perception of the riskiness of Japanese financial institutions other than Resona. In the second case, the test consists of comparing the spread levels before and after the event date in order to detect a material break (or "jump") in CDS pricing.

For our mean test $(i)$, we calculate the average spread changes for each day of the combined period (estimation and event windows) and then we sum over several days in the event window to obtain a measure of the cumulative average CDS spread change. The statistical significance of these measures can be judged by estimating the standard deviation of CDS spread changes over the estimation period.

CDS spread changes are simply calculated as $\delta s_{i, t}=C D S_{i, t}-C D S_{i, t-1}$, where $C D S_{i, t}$ is the CDS spread, expressed in basis points, for the financial obligor $i$ on a given day $t$. Previous empirical studies on the impact of credit rating changes on CDS pricing underlined the need to control for market-wide systematic factors when constructing CDS spread changes. As broad indices for the CDS market (e.g. iBoxx, TracX) have only recently been launched, Hull et al. (2004), Norden and Weber (2004), and Micu et al. (2004) among others, compute "rating-adjusted CDS spreads" by subtracting an index of spreads for a given rating from each CDS spread with the same rating. ${ }^{16}$ In this paper, we don't use rating-adjusted spreads because our CDS dataset contains a small number of reference entities. Particularly, as the number of components of the rating index is limited in our case, the test statistics might be biased toward zero. In addition, Hull et al. (2004) repeated all their tests without adjusting CDS spreads for general market conditions and found that the results, including the levels of significance, were unchanged.

The constant mean model (ii) is similar to the constant mean return model used in stock market event studies, viz. the CDS spread is modeled as $C D S_{i, t}=\mu_{i}+\zeta_{i t}$, where $\mu_{i}$ is the mean of the CDS spread and $\zeta_{i t}$ the time period $t$ disturbance term for financial obligor $i$ with an expectation $\mathbf{E}\left[\zeta_{i t}\right]=0$ and variance $\operatorname{Var}\left[\zeta_{i t}\right]=\sigma_{\zeta_{i}}^{2}$. For each day of the event window, the abnormal CDS spread is estimated as $\widehat{\zeta}_{i t}=C D S_{i, t}-\widehat{\mu}_{i}$, where $\widehat{\mu}_{i}$ designates the sample mean of the CDS spread over the estimation period. The cumulative abnormal CDS spread for event windows composed of days $\tau_{1}$ through $\tau_{2}$ is naturally defined

\footnotetext{
${ }^{16}$ Specifically, daily CDS spread index level is computed as the equally-weighted cross-sectional mean of all CDS spreads for a certain broad rating class (AAA and AA, A, and BBB) in the sample.
} 
as $C A S_{i}\left[\tau_{1} ; \tau_{2}\right]=\sum_{t=\tau_{1}}^{\tau_{2}} \widehat{\zeta}_{i t}$. The test statistics used to investigate whether the event of interest has a significant impact on CDS pricing are constructed in a similar way as those commonly used in stock market event studies.

\section{Data description}

To empirically study the eventual impact of Resona's bailout on other Japanese banks, we collect detailed pricing-relevant information from two markets: $(i)$ the stock market, and (ii) the credit derivatives market. This section briefly describes the sampling procedures and data sources used in our empirical analysis.

\subsection{Stock market data}

The stock market dataset is built using financial information reported in Datastream Thomson Financial database. We collect daily stock price data from April 25 ${ }^{\text {th }}$, 2002, to June $2^{\text {nd }}, 2003$, for all Japanese publicly traded banks. For stocks that were simultaneously listed on more than one exchange (Tokyo Stock Exchange, Osaka Securities Exchange, Fukuoka Stock Exchange, Nagoya Stock Exchange), pricing information is collected from the most actively traded exchange. ${ }^{17}$ Datastream reports daily opening, closing, high/low, bid/ask prices, as well as historical series of trading volumes. The price data are adjusted to reflect major capital events that include scrip issues/rights offerings, open offers, stock splits and consolidations, reductions of capital, and scrip (stock) dividends. ${ }^{18}$ Our initial sample, comparable in size to that used by Yamori and Kobayashi (2007), includes 97 banking organizations. However, contrary to the sample used by those authors, our final sample satisfies the following additional selection criteria:

- on the event day (May 19 $9^{\text {th }}, 2003$ ), the closing transaction price must be bounded by the closing bid and ask prices;

- by using LexisNexis ${ }^{\mathrm{TM}}$ Executive database, we imposed that major capital events such as stock splits, stock dividends, and other significant news (i.e. potentially "confounding events") did not occur on days surrounding Resona's bailout ("event window");

- we dropped all banks that had "thinly" traded stocks, defined as those for which daily stock price data were missing for more than six consecutive trading days. When a stock price was missing for less than six consecutive days, it was "padded" in time series, i.e. previous days' values were carried forward on days when the stock did not trade;

\footnotetext{
${ }^{17}$ Note that this is not necessarily the "home" exchange of the stock. In an analogous manner, for each bank listed on several exchanges, we considered the volume of trading from the exchange on which the stock has traded the most (i.e. had the highest volume for that stock) on any given day.

${ }^{18}$ The general principle upon which Datastream makes all adjustments is to render past data fully comparable with current data, from the perspective of shareholders. Consequently, the adjustments reflect changes in per share value rather than company performance.
} 
- finally, for a bank to be included in our sample, it must have no missing stock return data on the event date.

These selection criteria reduced our final sample to 93 banks: 8 money center banks, 56 first regional banks, 25 second regional banks, and 4 financial holding companies. To explain better the stock market reaction to the TBTF policy, we also collected financial information for each bank included in our final sample from Fitch-IBCA BankScope database. Credit rating information for a sub-sample of rated banks was obtained from various sources: Moody's Investors Service, Standard ES Poor's, Japan Credit Rating Agency, LexisNexis, and BankScope.

\subsection{CDS data}

The CDS dataset contains spread quotes supplied by two London-based providers of daily credit derivatives data, proprietary data, and analytics: Credit Market Analysis (CMA) and MarkIT Group Ltd (MarkIT). Both companies were founded in 2001 and are leading providers in the credit market field.

Since its creation Credit Market Analysis has spearheaded the effort to collect, clean, and provide market data on more than 7,500 credit derivative contracts. CMA receives CDS prices (or "spreads") from a range of market contributors (the so-called Data Consortium). These contributors consist of both buy and sell side institutions active in the fixed income markets such as asset managers, hedge funds, and banks. These active market participants provide both real-time and delayed prices of executed trades, firm or indicative bid/offers on specific reference entities, tenors, seniorities (ranking of the debt receiving moneys in case of default), and restructuring types (definition of what constitutes a default, ISDA agreement types). To ensure the highest level of accuracy, CMA checks these prices against previous quotes and uses a strict validation procedure. For less liquid entities where market activity is infrequent, CMA calculates the fair CDS spread using a proprietary issuer/sector curve model that derives an appropriate curve using known liquid CDS spreads, bond spreads and ratings data. Besides bid/offer rates, CMA also provides a qualifier ("veracity score") for each point of a specific CDS price time-series. The veracity score indicates the liquidity or, if applicable, the extent to which a value has been model-derived. For instance, a veracity score of 1 indicates an actual trade, a veracity score of 2 designates that the quote is a firm commitment to trade, whereas a veracity score of 3 implies that the quote is indicative. Veracity scores higher than 4 indicate derived spreads.

Our CMA sample includes all Japanese reference entities belonging to the financial sector for which CDS spreads were available from January 2003 to January 2004. ${ }^{19}$ This sample has 26 obligors (banks and other financial companies). Seven of these reference entities have been removed from our final sample because no CDS prices were available on the event date (May 19 $9^{\text {th }}, 2003$ ). Except quotes for three obligors, all other CDS quotes are

\footnotetext{
${ }^{19}$ Available credit history varies among reference entities with the earliest start date being January $1^{\text {st }}$, 2003.
} 
firm commitments to trade. That is, once quotes have been made, the contributing dealers are committed to selling/buying a minimal principal at the quoted offer/bid prices. For each financial obligor, we select CDS contracts with the most liquid maturities in order to reduce the size of liquidity premium. Our selection criteria are based on the level of the bid-ask spread, a commonly used measure of liquidity premium among market participants.

MarkIT Group Ltd provides CDS data on over 3,100 reference entities at various levels (tier/seniority, currency denomination, and document/restructuring clause). ${ }^{20}$ Historical data on CDS contracts are available from July 2001 forward. MarkIT centralizes over 850,000 CDS data points contributed by 74 global banks and 2 brokers. Each contributor provides data on CDS contracts from its books of record and from feeds to automated trading systems on a daily basis. The distribution of data across region and rating indicates that Asian entities represent about $20 \%$ of MarkIT universe and CDS trading is concentrated in entities rated A (26\%) and BBB (33\%).

It is worth noting that the "prices" reported by MarkIT do not represent actual prices at which CDS contracts have been traded or current offers to buy or sell credit protection at such prices. Particularly, all contributed quotes are subject to a data quality assurance protocol, which consists of several data cleaning tests (viz. stale data test, flat curve test, outlying data test, and backwardation test). Data that fail any of the filtering tests are excluded from subsequent calculations. The purpose of this set of rules is to ensure that all computations performed by MarkIT are made on a high quality dataset. When more than three contributors provide quotes that have passed the data cleaning tests (i.e. there is a quorum of data), MarkIT computes a "composite spread" on a daily basis. A "thin" composite spread is also reported where MarkIT has two prices that have passed data quality tests when at least one other price has failed. ${ }^{21}$

As in the previous case, we collect composite spreads for all Japanese financial entities (Industry Classification Benchmark (ICB) sector: "Financials", Industry-Level 1) over the period from May 2002 through June 2004. The sample includes 31 financial institutions. Following previous empirical studies on CDS pricing and MarkIT documentation, in our analysis we focus on the 5-year senior unsecured CDSs, which are the most popular contracts among market participants and, hence, the most liquid ones. According to International Swaps and Derivatives Association, Inc. (ISDA) agreements, for each CDS contract there are four options for treating the issue of restructuring, the most problematic credit event: Cum (With) Restructuring or Old Restructuring (CR), Modified Restructuring (MR), Modified-Modified Restructuring (MM), and Ex-Restructuring or Without Restructuring (XR). ${ }^{22}$ In our sample of financial obligors headquartered in Japan, the most frequently

\footnotetext{
${ }^{20}$ In the growing empirical literature on CDS pricing, data provided by MarkIT have also been used by other authors (Micu et al., 2004, Zhu, 2006, Jorion and Zhang, 2007, inter alia).

${ }^{21}$ MarkIT provides a daily statistical analysis of the data available across various asset classes (CDSs, Bonds, Convertibles, etc.). On average, $68 \%$ of the CDS daily quotes are rejected because they do not pass the data quality tests. Of the remaining clean spreads, $88 \%$ are quorate (i.e. valid composite spreads), whereas $8 \%$ are "thin" composite spreads.

${ }^{22}$ For more details about the exact definition of each of these documentation clauses see ISDA Credit
} 
used documentation clause is "CR." Consequently, we focus our analysis on a final sample of 5-year senior unsecured CDS contracts denominated in Japanese yen and having a "CR" documentation clause.

\section{Empirical results}

\subsection{Price limit hits and order flow imbalances}

Before presenting in greater detail the results of our event study analysis, we aim at drawing some preliminary inferences about the stock price reaction from the very peculiarities of the Japanese stock market and its microstructure features. Specifically, we are interested in cases where $(i)$ bank stock prices reached (or were close to reach) their maximum allowable limits and (ii) order flow imbalances occurred on days surrounding the bailout announcement date.

The Tokyo Stock Exchange (TSE) adopted the daily price limit system in 1950, by a directive from the General Headquarters of the Allied Powers, in order to protect investors against excessive volatility in market prices due to imbalances in the buy/sell equilibrium or due to speculative activities. ${ }^{23}$ By definition, the daily price limits impose a constraint that prevents stock prices to fluctuate outside a prespecified maximum range within a single trading day. ${ }^{24}$ As shown in Table 2, daily price limits $(d p l)$ are fixed in monetary units (Japanese Yen) in function of the level of the previous day's closing price $\left(x_{t-1}\right)$.

$\{$ Table 2$\}$

We use the following procedure to identify occurrences where prices were reaching (or approaching) their daily limits in the period surrounding the bailout announcement date. We begin by calculating for each bank security included in our sample and for each day in the event window, the price limits (upward $L_{t}$ and downward $\ell_{t}$ ) using data depicted in Table 2:

$$
\left\{\begin{array}{c}
L_{t}=x_{t-1}+d p l \\
\ell_{t}=x_{t-1}-d p l
\end{array}\right.
$$

Derivatives Definitions published in February 2003. As a general rule, the data cleaning tests used by MarkIT validate that the following condition is true for a contributor's spread: $\mathrm{XR}<\mathrm{MR}<\mathrm{MM}<\mathrm{CR}$. If a contributor reports data that do not conform to this rule, the non-default documentation clause spread is rejected.

${ }^{23}$ Besides the daily price limits, the TSE also utilizes tick sizes (i.e. minimum allowable units that prices may change from a trade to another) and quote parameters (i.e. maximum allowable trade-to-trade price changes) to prevent short-tem wild variations in market prices. The TSE price stabilization mechanism has been changed seven times since it was created, the most recent change being made in 2000. According to TSE officials, the other regional exchanges (viz. Osaka Securities Exchange, Fukuoka Stock Exchange, and Nagoya Stock Exchange) are using the same price stabilization mechanism as that used on TSE.

${ }^{24}$ Note that price limits do not prohibit trading per se, but only trading beyond the settled maximum interval. Consequently, stocks may be traded after a limit hit, as long as subsequent transactions take place at prices lower (higher) than the upper (lower) barrier. 
Then, we compare the highest (lowest) price achieved on day $t, \bar{x}_{t}\left(\underline{x}_{t}\right)$, to the upward (downward) limit, $L_{t}\left(\ell_{t}\right)$. The price limit hit indicators are defined as follows:

$$
U_{p H i t}=\left\{\begin{array}{l}
0 \text { if } \bar{x}_{t}<L_{t} \\
1 \text { if } \bar{x}_{t} \geq L_{t}
\end{array}, \text { DownHit } t_{i t}=\left\{\begin{array}{l}
0 \text { if } \underline{x}_{t}>\ell_{t} \\
1 \text { if } \underline{x}_{t} \leq \ell_{t}
\end{array}\right.\right.
$$

We use the weak inequality operators in the definition of $U p H i t_{i t}$ and DownHit $t_{i t}$ because there are some cases in our sample where stock prices jump beyond their limits. ${ }^{25}$ According to TSE officials, the so-called "base price" used in the calculation of daily price limits is given by the previous day's closing price as reflected in Table 2, except in cases where TSE indicates a "special quote" or it is an ex-dividend date. ${ }^{26}$ However, daily price limits are set wide enough so that limit hits only exceptionally occur. Indeed, we are able to identify in our sample one single downward-limit-hit (Resona) on day 0 and two upwardlimit hits (Resona and MFG, two banks included in our TBTF1 sample) on day +2 (see Table 3). As occurrences of stock prices reaching their limits are rather rare events, we also considered cases where prices come close to hitting the upper/lower barriers. The corresponding indicators are defined in an analogous manner:

$$
\text { NearUpHit } i t=\left\{\begin{array}{l}
0 \text { if } \bar{x}_{t}<90 \% \times L_{t} \\
1 \text { if } \bar{x}_{t} \geq 90 \% \times L_{t}
\end{array}, \text { NearDownHit } t_{i t}=\left\{\begin{array}{l}
0 \text { if } \underline{x}_{t}>110 \% \times \ell_{t} \\
1 \text { if } \underline{x}_{t} \leq 110 \% \times \ell_{t}
\end{array}\right.\right.
$$

Data reported in Table 3 indicate that three banks included in the TBTF samples experienced large drops in value on day $0\left(\right.$ NearDown Hit $\left.i_{i 0}=1\right)$, whereas four out of five TBTF banks saw their stock prices rise close to the upper barrier on day $+2\left(\right.$ NearUpHit $\left._{i 2}=1\right)$. In addition, the percentages of near limit hits are significantly lower in the non-TBTF samples.

$\{$ Table 3\}

Systematic flow patterns in the order book following the bailout announcement date can also be identified by analyzing standard microstructure variables, such as the number of closing quotes at the bid/ask or the proximity of the closing prices to the bid/ask quotes, measured by the order flow ratio:

$$
\text { Order flow ratio (\%) }=\frac{\text { Closing Ask }- \text { Closing Price }}{\text { Closing Ask }- \text { Closing Bid }} \times 100
$$

\footnotetext{
${ }^{25}$ For instance, Resona stock price dropped beyond the downward limit on May 19 , 2003 (the "event day") and then moved beyond its upward limit on days +2 and +3 . Kim and Rhee (1997) conducted an original empirical analysis on the (in)effectiveness of the price stabilization mechanism prevailing in the TSE at the beginning of the nineties. They also discovered in their sample occurrences where high (low) prices were greater (lesser) than their allowed price fluctuation.

${ }^{26}$ The second exception is not relevant to our analysis since all Japanese banks distributed dividends at the end of June 2003, i.e. outside our event window. Special quotes are another TSE price stabilization mechanism aiming to prevent intra-day excessive fluctuation in market prices. They can be issued at any time during the trading session if a marked order imbalance exists between bids and offers. The special quotes are renewed every five minutes until the market equilibrium is achieved. If the order imbalance persists at the close of trading, the special quote is used instead of the closing price as a base price to determine the next day's price limits.
} 
For TBTF banks, the mean (median) order flow ratio on day 0 is closer to $100 \%$, indicating a selling pressure. However, the TBTF banks do not exhibit order flow ratios significantly higher (in a statistical sense) than those calculated for non-TBTF banks. Conversely, the mean (median) ratio on day +2 nearer to $0 \%$ for TBTF banks is indicative of an excess of buy orders and, hence, of a buying pressure. Moreover, comparing the order flow ratios on day +2 across TBTF and non-TBTF samples yields a statistically significant difference according to the mean (t-test) and median (Wilcoxon-Mann-Whitney and Kruskal-Wallis) tests.

Overall, the preliminary evidence presented in this section indicates that the bailout announcement resulted in a movement of stock prices of large Japanese banks toward the lower price limit and closing bid quote on day 0. More importantly, the downward pressure on prices was reversed on day +2 , when we observe a predominance of buy orders and a rebound of prices toward their upper daily limit. Yet, this sinuous pattern is highly specific to the banks included in our TBTF samples. We return to the interpretation of this wide swing in stock market prices of large Japanese banks in the next section.

\subsection{Evidence of TBTF effects in stock prices and volume of trading}

To refine our preliminary findings, we report in Table 4 the results of the conventional event study analysis described in Section 2, separately for the full, TBTF1, and non-TBTF1 samples. ${ }^{27}$ On average, the abnormal returns calculated over the event window are not statistically significant for the entire sample of banks, except for the event day $(t=0)$. However, aggregating all data into a single global sample could mask significant heterogeneity among listed banks. Scrutinizing Table 4, we can observe that the Top5 banking organizations included in the TBTF sample experience a significantly negative abnormal return of $-5.58 \%$ according to the parametric test on the first trading day following the bailout announcement. The other banks show smaller non-significant negative abnormal returns. The $t$-statistic reported in the last column of Table 4 indicates that the difference in average abnormal returns between the two sub-samples is significant at the $1 \%$ level.

\section{$\{$ Table 4$\}$}

The negative effect of the Resona crisis on the largest banking organizations in the country was reversed two days latter, on day +2 , when additional details about the bailout were disclosed. Particularly, the government publicly announced that Resona's shareholders will not incur any losses after the capital injection (see Appendix 2 and Yamori and Kobayashi, 2007). Not surprisingly, this statement was perceived as favorable news for the shareholders of the other large banks. Indeed, as reflected in Table 4, these banks show a significantly

\footnotetext{
${ }^{27}$ We also conducted our event study analysis using the alternative partition of the full sample (i.e. TBTF2 banks vs. Non-TBTF2 banks). The results remain statistical significant and are very similar to those reported in Table 4. However, as expected, the levels of significance are somewhat weaker. For the sake of space, we decided not to report these additional results. Also, to save space, we only report in Tables $4 \& 5$ the results for a smaller (eleven-day) window surrounding the event day.
} 
positive abnormal return of approximately $+8.40 \%$ on day +2 according to both parametric and non-parametric tests. By contrast, the other banks included in the non-TBTF sample experience a negative (though non-significant) abnormal return on the same day. The difference in average abnormal returns between the two sub-samples is once again statistically significant at the $1 \%$ level.

These results are reinforced by the analysis of the cumulative abnormal returns (CAR). The CARs computed over whatever window are not significantly different from zero neither for the full sample nor for the non-TBTF sample. Yet, the largest banks show a significant CAR over the post-event windows: negative at the beginning of the crisis $(-7.11 \%)$ and positive over the $[+2 ;+3]$ window. The highly significant positive CAR of $+12.55 \%$ over the $[+2 ;+3]$ window is confirmed by both parametric and non-parametric tests. It is worth noting that the decision made by the Japanese government to manage the Resona crisis and to bail out the bank was not anticipated by investors. None of the abnormal returns are significantly different from zero during the period preceding the event day.

The results of the event study methodology applied to trading activity confirm the asymmetric pattern characterizing the reaction of stock prices to Resona's bailout. As reflected in Table 5, we detect a significant abnormal volume of trading on days following the bailout announcement date (days 0 through +3 ) only in the TBTF sample. We also find, as expected, that the abnormal trading volume for the largest banks is statistically higher than that of the other banks included in the non-TBTF sample (see the last column of Table 5). As in the previous case of abnormal stock returns, the hypothesis concerning the existence of an information leakage prior to the bailout announcement is not supported by the data: no significant abnormal trading activity occurred during the period preceding the event day. The parametric and non-parametric tests applied to the cumulative abnormal volume of trading computed over various pre- and post-event windows fully confirm the above results.

\section{$\{$ Table 5\}}

The event study analysis of the volume of trading, taken separately, does not allow us to draw any statistical inference with respect to the direction of the pressure exerted on stock prices by the abnormal trading activity observed immediately after the bailout announcement date. However, the corroborating microstructure evidence discussed in the previous section helps us refine our understanding of the stock market reaction. Specifically, the abnormal trading activity during the first week after the event date was induced by an excess of sell orders (and a downward pressure on prices) on day 0 , followed by a predominance of buy orders (and a rebound of stock prices) on days +2 and +3 .

To resume our findings, during the first week after the Japanese government revealed its intention to bail out the $5^{\text {th }}$ financial group in the country, stock market participants swung between fears and opportunities. At the very beginning of the crisis, they feared that the government will act as it did in the past by nationalizing the bank and imposing 
losses on shareholders. ${ }^{28}$ The announcement of additional details about the bailout and the resolution process contributed to calm down the private market participants. They viewed the large banks' stocks as a good investment opportunity. Consequently, we see the positive abnormal returns experienced by the largest financial groups on days +2 and +3 as an obvious manifestation of the TBTF doctrine in Japanese banking.

\subsection{Determinants of stock market reaction to the bailout announcement}

After providing evidence that market participants were not indifferent to the Japanese government's commitment to rescue the $5^{\text {th }}$ financial group in the country, we investigate in this section the economic determinants of the stock market reaction to the bailout announcement. In this respect, we focus on a large set of financial variables capturing three main dimensions of banking performance, namely, risk profile, profitability, and bank capitalization. All balance-sheet variables are measured by using accounting data reported by each individual bank for the fiscal year ending March $31^{\text {st }}, 2003 .{ }^{29}$

The risk profile is proxied by the ratio of net charge-offs to average gross loans and the loan loss provisions divided by the net interest revenue. Higher values of these ratios indicate a deteriorated credit risk profile. An alternative proxy for the banking risk is the market measure of the probability of bank failure, computed as the ratio of the variance of equity returns over the estimation window divided by one plus the average equity return over the same window, squared (see Appendix 3 for more details). The profitability is expressed by the return on average assets (ROA) ratio, the net interest revenue / average assets ratio, and the net interest margin. Finally, the bank capitalization is measured by the equity / total assets ratio and market leverage (i.e. the ratio of total debt to the market value of common stock plus the book value of preferred stock). To examine the role of deferred tax accounting in explaining the stock market reaction we also compute the ratio of deferred tax assets to total equity.

As a broad market measure of banking risk and financial conditions, we use the credit ratings assigned by international rating agencies (Moody's and $S E \mathcal{E}$ ) and local raters (Japan Credit Rating Agency, Ltd. (JCR) and Rating and Investment Information, Inc. (R\&I)). These ratings represent an appreciation of the capacity of a bank to honor its senior unse-

\footnotetext{
${ }^{28}$ For instance, this is exactly what happened when Long-Term Credit Bank of Japan and Nippon Credit Bank, two large commercial banks, were confronted with financial distress at the end of 1998. For the first time since the end of World War II, the Japanese authorities decided to impose substantial losses on the shareholders of these banks. Consequently, the crisis resolution process was expected at that time to largely remove any implicit subsidy generated by TBTF-type policies. Brewer et al. (2003) provide a detailed analysis of these failures and their impact on the stock prices of the surviving banks.

${ }^{29}$ Note that the financial statements of Japanese banks are disclosed several weeks after the end of the fiscal year. Consequently, we suppose implicitly that accounting information is already incorporated in stock market prices collected over the first week that follows the announcement date. Our tests would then be biased against finding a significant relationship between the stock market reaction and various financial ratios. We avoid using the interim financial reports disclosed on September $31^{\text {st }}, 2002$, as has been done by Yamori and Kobayashi (2007), because these reports are not audited by outside parties.
} 
cured long term financial commitments, denominated in local/foreign currency. The agencies use relatively similar scales and criteria, and assign rather comparable ratings. Although the traditional credit ratings are synthetic market measures of a bank's financial conditions, they do not necessarily reflect the genuine risk profile of the issuing bank. Particularly, in the presence of de facto TBTF governmental guarantees, the capacity of an entity to honor its debt service could be excellent even if its intrinsic financial conditions are poor. ${ }^{30}$ Moody's has soon recognized this problem and proposed new ratings, focused on the intrinsic safety and soundness of banks, which exclude certain external credit risks and credit support elements addressed by traditional ratings. These "financial strength" ratings, assigned exclusively to banks and insurance companies, can be considered as an objective evaluation of the likelihood that a financial institution needs to seek an outside support, either from authorities or its shareholders. The traditional credit ratings are converted to cardinal value according to the following scale: $\mathrm{AAA} / \mathrm{Aaa}=1, \mathrm{AA}+/ \mathrm{Aa} 1=2, \mathrm{AA} / \mathrm{Aa} 2=3$ etc., and then averaged across rating agencies. Hence, a lower cardinal value corresponds to a higher credit quality.

Besides the size, we wonder whether there is any other significant difference between the two samples of banks (TBTF vs. non-TBTF banks) that could explain the asymmetric reaction of the stock market to the bailout announcement. To address this question, Table 6 summarizes the results of a bivariate comparison of risk, profitability and bank capitalization variables. Specifically, we compare the distribution of each bank performance variable in the two sub-samples of banks by performing a standard $t$-test and two non-parametric tests: Wilcoxon-Mann-Whitney and Kruskal-Wallis. The symbols "》" ("《") and ">" ("<") indicate that the left-hand mean or median value is greater (lower) than the right-hand mean or median value at the $1 \%$ and $5 \%$ level, respectively.

\section{$\{$ Table 6\}}

As revealed by the data, the largest banks included in the TBTF sample are less profitable on average and more leveraged than their smaller competitors. As expected, the deferred tax assets are more extensively used by the largest banks in order to artificially boost their capital ratios. ${ }^{31}$ As far as the risk profile is concerned, it is apparent that the credit quality is significantly more deteriorated in the TBTF sample. This result is

\footnotetext{
${ }^{30}$ For instance, Moody's explicitly recognizes that "the rating determinants for Japan's banks are not their financial fundamentals, such as solvency levels, but rather perceived franchise values and the probability of regulatory support. The level of such support is, in turn, determined by how importantly the regulators view each entity. [...] the process of rating banks is becoming more an exercise in determining, for each rated institution, the likelihood of government support, as opposed to assessing the necessity for outside supportas with a bank financial strength rating. In this sense, the focus of any analytical exercise is more on arriving at qualitative distinctions on the predictability of support for any institution" (Banking System Outlook, Moody's Investors Service, January 2004, emphasis added)

${ }^{31}$ Skinner (2006) provides convincing empirical evidence that the largest Japanese banks extensively used deferred tax accounting to artificially boost their regulatory capital ratios. More importantly, deferred taxes have also been used by bank regulators as an instrument of regulatory forbearance, i.e. to create the false appearance that the mega bank groups were comfortably capitalized. In fact, this accounting tool allowed the
} 
Figure 1: Deposit/debt ratings vs. financial strength ratings for large Japanese banks

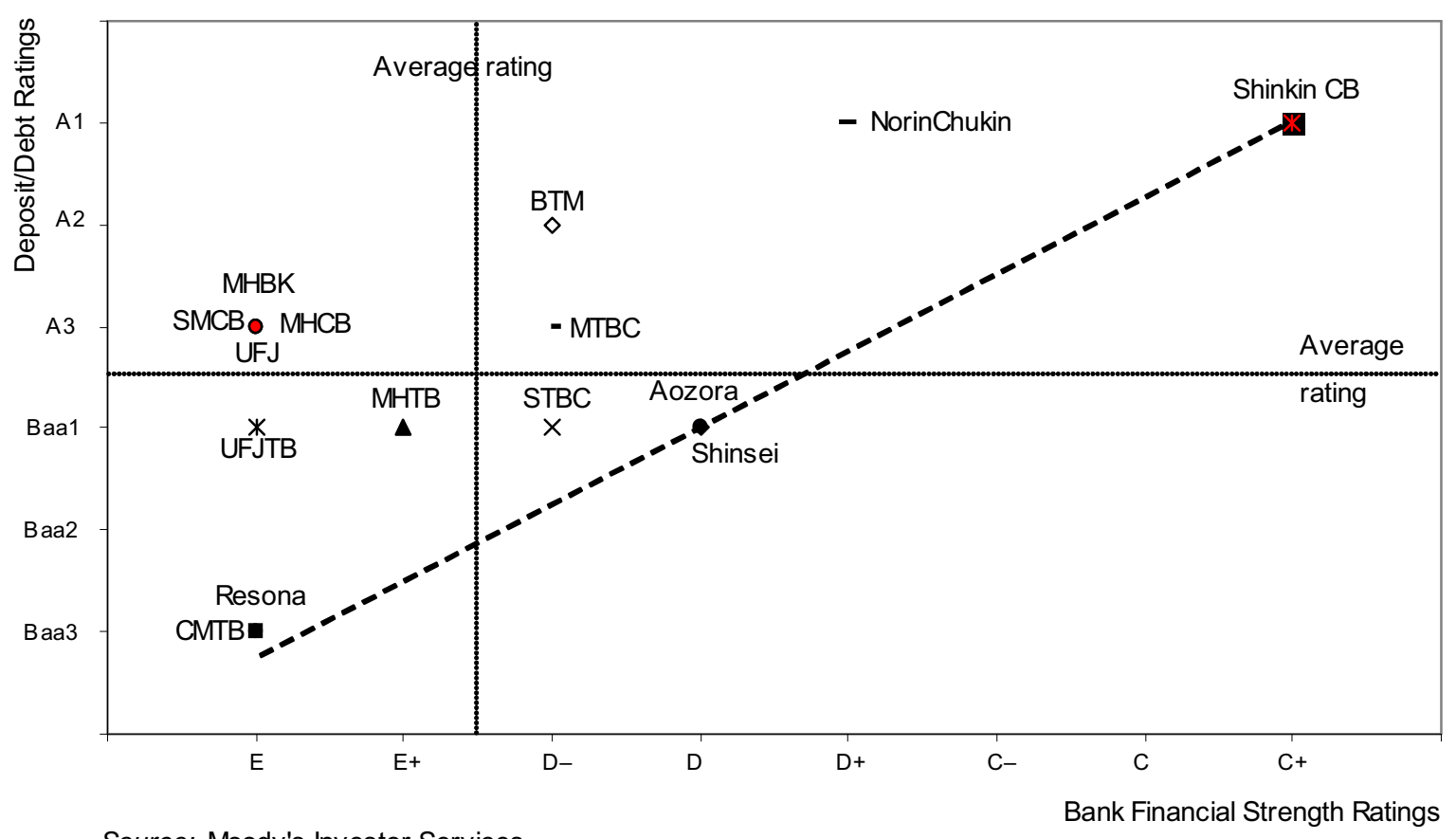

Source: Moody's Investor Services

strengthened by the bivariate analysis of credit ratings. Although the traditional ratings are not statistically different between the two sets of banks, the intrinsic financial health of the largest Japanese banks is rather poor (12.53 or E) compared to that of the non-TBTF banks (9.80 or D). Moreover, the difference between traditional and financial strength ratings is higher in the TBTF sample (4 notches) than in the non-TBTF sample (1 notch), indicating that the Japanese safety net is more generous with large banks. ${ }^{32}$ Figure 1 gives a suggestive illustration of this result. Because of the high likelihood of regulatory support, the largest banks placed above the diagonal line and toward the north-west corner received better debt ratings than their intrinsic risk profile would imply.

We also report in Table 6 descriptive statistics for other control variables: the turnover ratio (i.e. the number of shares traded divided by the number of outstanding shares), total assets, bid-ask spread (i.e. the difference between closing ask and bid), intraday

Japanese government to postpone the adoption of more drastic and politically unpopular economic measures to deal with the serious financial problems experienced by large banks.

${ }^{32}$ By examining the differences between the two types of ratings (traditional vs. financial strength ratings) on a large sample of rated banks, Rime (2005) shows that TBTF expectations significantly boost large banks issuer ratings. The TBTF proxies have a significant impact on issuer ratings and this impact is larger for banks exhibiting low financial strength ratings. Our findings are also consistent with the discussion about credit rating agencies in Stern and Feldman (2004, chapter 4), according to whom comparisons between the two types of ratings are an interesting way of identifying financial firms that could benefit from the TBTF protection. 
maximum range (i.e. the difference between the highest and lowest price achieved on day $t$ ), and free float (i.e. the percentage of total shares in issue available to ordinary investors). All microstructure variables are averaged over days 0 through +3 . By design, the total assets are significantly higher in the TBTF sample ( $\$ 852$ billion against $\$ 33.48$ billion). The turnover ratio and intraday maximum range are also significantly higher in the TBTF sample indicating a higher trading activity and intraday price variation for large banks.

Table 7 reports the correlation coefficients between standardized cumulative abnormal returns (SCAR) and standardized cumulative abnormal volume of trading (SCAVT), on the one side, and a group of factors that could explain the market's reaction to the bailout announcement. SCAR and SCAVT are computed over various post-event windows in order to take into account the wide swing in stock market prices for large banks that we documented in previous sections. If we focus on the market reaction on days +2 and +3 , SCAR is positively correlated with all the risk measures and negatively correlated with the profitability variables. That is, the more deteriorated the banking performance, the stronger the reaction of stock market prices to the bailout announcement. This result is confirmed by the strong positive correlation between SCAR and Moody's financial strength ratings. Among the bank capitalization measures, only the market leverage is positively related to SCAR estimated over the window $[+2 ;+3]$. As far as SCAVT is concerned, the signs of the correlation coefficients remain basically the same, but the levels of significance are weaker.

\section{$\{$ Table 7$\}$}

As previously anticipated, the logarithm of total assets and the TBTF dummy variables, which take the value of 1 if a bank belongs to one of the two TBTF samples, are strongly and positively correlated with both SCAR and SCAVT. This result is fully consistent with the preliminary findings discussed in the preceding sections. Not surprisingly, the intraday maximum range and the turnover ratio are also positively correlated with the two variables capturing the stock market's reaction.

The main results of the univariate comparison are confirmed by our cross-sectional (multivariate) analysis that consists of regressing SCAR estimated over the window $[+2 ;+3]$ on the group of factors defined at the beginning of this section (see Table 8). ${ }^{33}$ To mitigate the drawback related to credit ratings cardinalization (implicitly assuming a linear relation between ratings and bank performance), we replace the continuous variables with three dummies for each rating class (D1, D2, and D3). The assignment of ratings to different classes is based on the average of S\&P and Moody's, and JCR and R\&I, respectively, and Mody's Financial Strength ratings (cardinalized values). The best class variable D1 (i.e. AAA/Aaa and A) was dropped in order to avoid multicollinearity. As reflected in Table 8 (Models 2 and 4), the coefficients of the rating variables are positive and statistically

\footnotetext{
${ }^{33}$ In an alternative specification, we also considered the abnormal volume of trading (SCAVT) as the dependent variable in the various empirical models depicted in Table 8. The results are very similar but the levels of significance are not as high as those reported in Table 8. For the sake of space, we do not report these results.
} 
Figure 2: The "moral hazard rally" among Top 5 Japanese banks listed on TSE

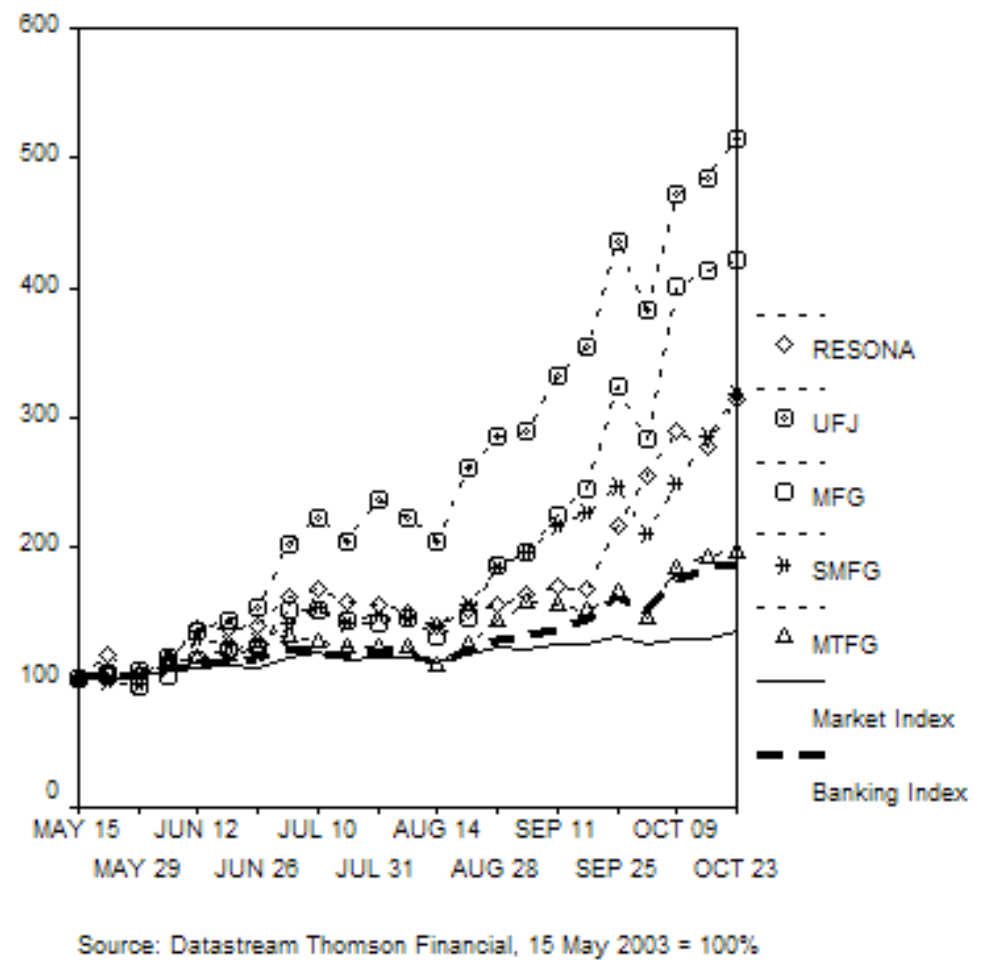

significant, ranking according to the considered rating classes $(\mathrm{D} 2<\mathrm{D} 3)$. The stock market reaction appears to be stronger for the low-rated banks and banks in poor intrinsic financial health. ${ }^{34}$ This finding is still valid if we replace the rating dummy variables by other proxies for bank fundamentals (Models 5-8, Table 8). Given the paper focus, probably our most relevant result is that the TBTF dummy variable exhibits a positive and strongly significant (at the 1\% level) coefficient, as expected. That is, even after controlling for banking risk and financial conditions, the stock market reaction to the bailout announcement is much stronger for the largest banks.

\section{$\{$ Table 8\}}

Overall, the results presented in this section lend empirical support to many analysts' view (see e.g. Fukao, 2004), according to which after Resona's bailout, the stock prices of the most fragile financial institutions rose more than those of sound firms. The rescue of the $5^{\text {th }}$ financial group in Japan triggered a so-called "moral hazard rally" among the largest banks listed on TSE, not only in the short run but also in the long run. As illustrated in

\footnotetext{
${ }^{34}$ The coefficients of the credit ratings assigned by the local agencies (JCR and R\&I) are positive but not statistically significant at conventional levels (Model 3, Table 8). By investigating the stock price reaction to rating changes in the Japanese market, Li et al. (2006) conclude that global agencies (Moody's and SEPP) are more influential than the two major local raters, JCR and R\&I.
} 
Figure 3: OTC credit derivatives and CDS contracts on Japanese entities (US\$ millions)

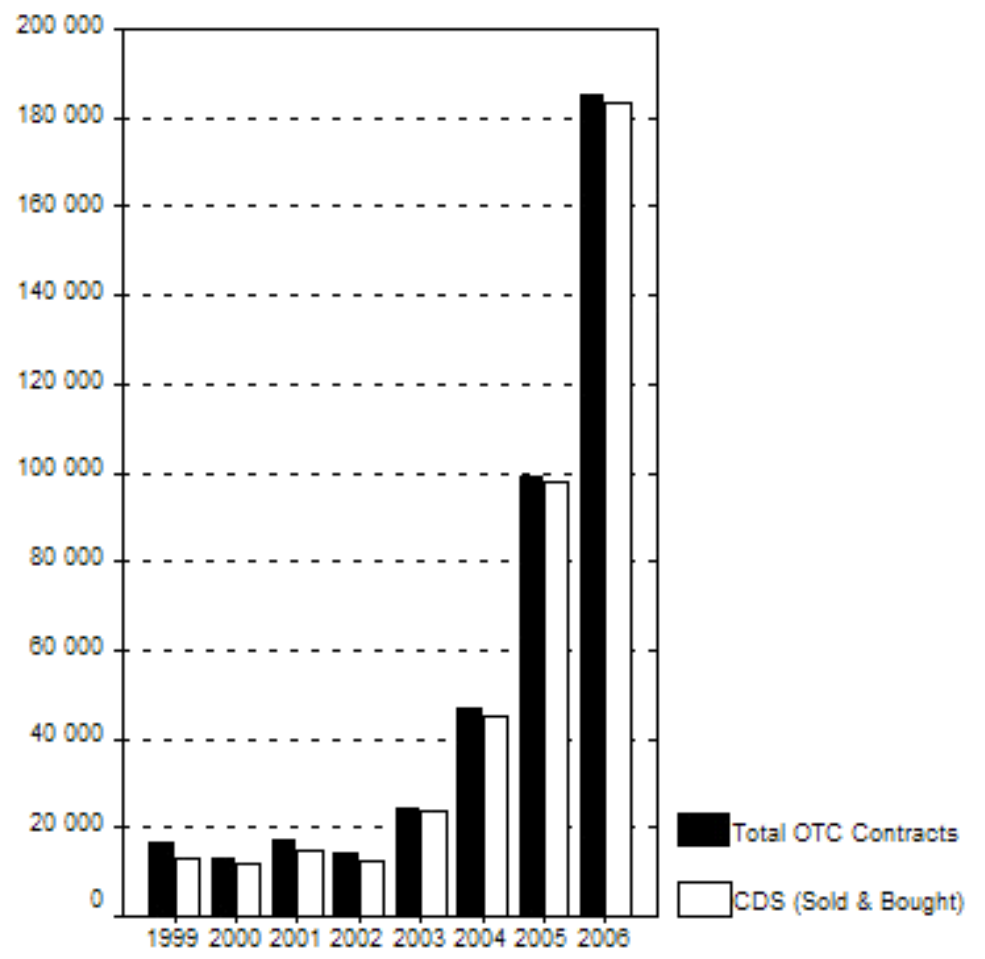

Figure 2, the equity market values of the five Japanese mega banks rebound sharply in the post-bailout period. For the purpose of comparison, we also represented in the same figure the evolution of two benchmarks: $(i)$ the Japanese broad market index, TOPIX, and (ii) the banking index, TOPIX BANKS. The recovery of stock prices of the Top5 banks was much stronger than that of both the market and banking index. Our results suggest that a large portion of this spectacular recovery can reasonably be explained by invoking conventional TBTF-type arguments.

\subsection{Detecting "pure" risk effects in CDS pricing}

In Japan, credit derivative contracts have been recognized by law as financial instruments since November 1998. The largest Japanese banks started using credit derivatives as an effective tool to hedge their credit portfolios and to overcome regulatory and economic capital constraints. Stimulated by the increase in default rates among Japanese corporate issuers, the credit derivatives market has grown exponentially over the past few years. According to the Yoshikuni Statistics compiled by the Bank of Japan, from 1999 to year-end 2006 , the total amount of OTC credit derivative contracts (sold and bought) grew from $\$ 16$ billion to $\$ 184$ billion (see Figure 3 ). The Bank of Japan statistics also show that singlename CDSs are by far the most popular financial instruments among market participants, 
Figure 4: Sumitomo Mitsui Banking Corp - CDS quotes (bps) before and after the announcement of Resona's bailout

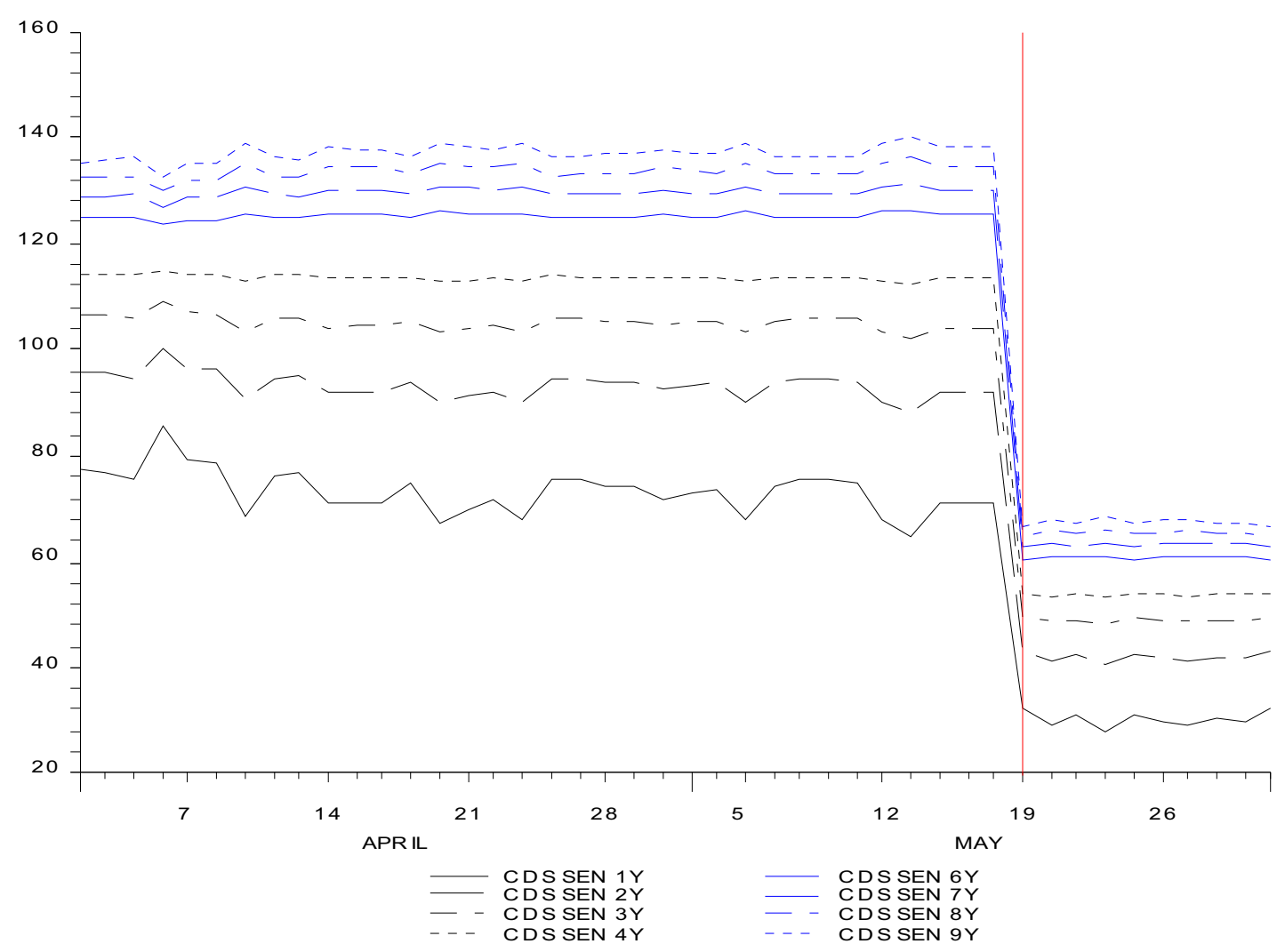

accounting for approximately 78\% in 1999 (99\% in 2006) of the Japanese market for credit derivatives.

The list of the reference entities included in our two CDS samples (CMA and MarkIT, respectively) is presented in Table 9 . We also report the average of the Moody's and S\&P ratings rounded to not include the "+" and "-" levels. Initially, our CDS samples contain 26 (CMA) and 31 (MarkIT) financial obligors, respectively. However, after dropping all the reference entities for which no CDS prices are available on May $19^{\text {th }}$, 2003 (i.e. the "event date") or for which the veracity score indicates model-derived spreads, our final CMA sample is further reduced to 16 financial firms. While the number of reference entities included in our CDS samples is relatively low, CMA and MarkIT constitute some of the best data sources on credit derivatives available in 2003 .

\section{$\{$ Table 9\}}

If the market participants interpreted the government intention to rescue Resona Holdings as an enhancement of the TBTF doctrine, then we might expect large financial obligors to have been perceived as safer reference entities after May $19^{\text {th }}, 2003$, relative to the pre- 
event period. Otherwise speaking, we anticipate large drops in the probability of default and, hence, in the market price of risk after the event date for at least some of the underlying entities included in our sample. This original "pure" risk effect attributable to the strengthening of the TBTF policy is illustrated in Figure 4, displaying the time evolution of CDS mid-quotes for Sumitomo Mitsui Banking Corporation, the wholly-owned subsidiary of SMFG, one of the five largest financial groups in Japan. As expected, the market reaction was quick and economically significant: depending on the maturity of the CDS contracts, the downward revision of the market prices of risk varies between 40 bps (for the 1-year CDS) and 70 bps (for the 10-year CDS).

To further investigate the risk effects of the bailout announcement, we present in Table 10 individual and average changes in CDS spreads (expressed in basis points) on various periods surrounding the event date. On average, the CDS change is significant and negative on day $0(-42.46 \mathrm{bp}, p<0.01)$ for the reference entities included in the CMA sample (Table 10, Panel A). Moreover, the cumulative change over the first week after the bailout announcement is also statistically significant, even if no significant change is detected on each post-event day (apart Monday, May $19^{\text {th }}$ or day 0). We confirm this finding using the alternative statistical test based on the constant mean model described in Section 2.3 (unreported result). Applying the same methodology to the financial obligors included in the MarkIT sample leads, however, to statistical insignificant results (Table 10, Panel B) irrespective of the currency, maturity and restructuring clause of the CDS contracts. The composite CDS spreads extracted from MarkIT's database appear to be "stale" over the period surrounding the bailout announcement date for all the reference entities in our sample. In their study on credit contagion, Jorion and Zhang (2007) examine a large CDS dataset sampled from MarkIT and document that spreads does not necessarily change from one day to the next. Specifically, about $37 \%$ of daily observations in their sample display no change from the previous day, on average. They attribute this finding to the fact that there is no sufficiently new and material information affecting the obligors to justify changing quotes by contributors. This explanation clearly does not apply in our case, as we detect a significant impact of the bailout announcement in the stock and CDS markets using an alternative source of information. A second candidate explanation could be that the two providers of credit information use substantially different data quality assurance protocols, data cleaning tests, and methods for converting individual contributed spreads to a "composite" spread. In light of these contrasting findings, comparing CDS data extracted from alternative sources of credit market information is certainly an interesting avenue for future research. ${ }^{35}$

$\{$ Table 10\}

\footnotetext{
${ }^{35}$ To our knowledge, there is only one study that examines this issue in a different context. Hancock and Kwast (2001) compare bond data extracted from several sources of information and conclude that the disparities between alternative sources are quite large.
} 


\section{Conclusion}

Previous empirical studies using Japanese stock market data document that, after the collapse of large banks and securities firms at the end of the nineties, the monitoring of private investors efficiently translates into informative prices, which could be used as earlywarning signals to complement regulatory discipline. More recently, Hoshi and Kashyap (2004) also propose an interesting channel of market discipline in Japanese banking: the use of market signals as a tool of "selective rehabilitation" to decide which banks merit public funding. In their view, banks that are better valued in the market and can attract arms-length financing at a reasonable cost (as part of the restructuring plan) should be more likely to receive financial support from the government. Conversely, banks that can raise capital only from affiliated parties, on suspiciously favorable terms, might have less chance to be rescued from failure. By reviewing the earlier empirical literature using pre-2000 data, Genay (1999) concludes that market discipline on Japanese banks is ... "alive and well."

The empirical evidence presented in this paper suggests that this overall optimistic view on the functioning and virtues of market discipline in Japanese banking may no longer be valid in the post-Resona period. Consistent with Yamori and Kobayashi's (2007) study, we find significant positive wealth effects in the stock market accruing to the largest Japanese banks on days following the bailout announcement. We also provide evidence for the existence of a TBTF status by analyzing trading volumes, key microstructure variables, and significant changes in the investors' perception of the riskiness of Japanese financial institutions in the fast-growing market for credit derivatives.

By deciding to embrace the reputed TBTF doctrine and fully protect the uninsured creditors and equityholders against the risk of loss, the public authorities ultimately found their own nemesis in the structural weaknesses of market discipline. They created a hostile environment for effective market discipline, in which the incentives of large and sophisticated creditors and other private counterparts to monitor and influence risk taking behavior are irremediably compromised. The distorted incentive structure has, in turn, a major impact on the quality of the Hayekian information disseminating process accompanying the price formation mechanism. As the stock prices of low-rated banks and banks in poor intrinsic financial health are found to be much higher than those of sound firms after Resona's bailout, the usefulness of market information for supervisory purposes appears to be limited at best. In our view, the Resona episode was tantamount to applying a coup de grâce to market discipline. The way the bailout was organized clearly illustrates that major Japanese banks are practically impossible to liquidate from the regulator's point of view. Hence, the market discipline approach is prima facie excluded for these banks. 


\section{Appendix 1: The Asymptotic Relative Efficiency (ARE) indicator}

This appendix briefly describes the computation of the Asymptotic Relative Efficiency (ARE) indicator reported in Tables $4 \& 5$. More details about the definition of the ARE indicator can be found in classical textbooks and monographs on nonparametric statistics (see e.g. Hettmansperger, 1984). The indicator was successfully used by Campbell and Wasley (1996) to compare the power (i.e. the ability to detect existing differences or to reject a null hypothesis) of a rank test relative to that of a standard parametric $t$-test.

One of the disadvantages of nonparametric tests is that they discard certain information about the structure of the underling data. For instance, Corrado (1989) rank test statistic reported in Tables $4 \& 5$, while preserving information about the genuine order of the data, totally ignores the actual values taken by the variables of interest. As some relevant information may be lost when applying nonparametric procedures, it is useful to define a measure of how much information is discard in the process. One such measure is the ARE indicator, defined as follows:

$$
A R E=12 \sigma^{2}\left[\int_{-\infty}^{+\infty} \varphi^{2}(\epsilon) d \epsilon\right]^{2}
$$

where $\sigma^{2}$ designates the variance and $\varphi(\epsilon)$ the pdf of the underling data. As the ARE indicator is invariant across the mean and variance of $\epsilon$, it is convenient to standardize the variable $\epsilon$ by setting its mean to 0 and its variance to 1 . The pdf $\varphi(\epsilon)$ can be approximated by using a Gramm-Carlier expansion as follows:

$$
\varphi(\epsilon) \approx \frac{\exp \left(-\epsilon^{2} / 2\right)}{\sqrt{2 \pi}}\left[1+\frac{\alpha_{3}}{6}\left(\epsilon^{3}-3 \epsilon\right)+\frac{\beta_{4}-3}{24}\left(\epsilon^{4}-6 \epsilon^{2}+3\right)\right]
$$

where $\alpha_{3}$ and $\beta_{4}$ are the skewness and kurtosis of the variable $\epsilon$. By using this approximation for the pdf, the ARE indicator can be rewritten in a more convenient following way:

$$
A R E \approx \frac{3}{\pi}\left[1+\frac{5}{96}\left(\alpha_{3}^{2}\right)+\frac{105}{96^{2}}\left(\beta_{4}-3\right)^{2}+\frac{\beta_{4}-3}{16}\right]^{2}
$$

By definition, ARE is highly dependent on the non-normality of the underlying data $\left(\alpha_{3} \neq 0, \beta_{4} \neq 3\right)$. Particularly, if the data come from a normally distributed population (i.e. $\alpha_{3}=0, \beta_{4}=3$ ), ARE is approximately equal to 0.955. As a general rule, if the ARE indicator takes values greater than unity, we can infer that Corrado (1989) rank test dominate the standard parametric $t$-test. To give the intuition behind this rule, it is worth noting that, in the particular case of small samples, for standard parametric $t$-tests to be valid, the underlying observations must be drawn from a normally distributed population. If it is not the case, the resulting statistical inferences might be misleading. However, the nonparametric tests may be used instead to produce valid inferences about whether two samples are drawn from the same population. 


\section{Appendix 2: Excerpts from the press conference by the Minister for Financial Services $^{36}$}

Question (Q): Your determination on the necessity of public fund injection was supposedly made to avoid a crisis. Will you explain the ground for this determination?

Answer (A): The Article 102 of the Deposit Insurance Law prescribes a measure to be taken in a so serious case that it may adversely affect the orderly functioning of financial markets. In view of the significance of the scale and the foundation of activities of the Resona Bank, we held a Financial System Management Council meeting and determined capital injection into the bank. All these moves represent our strong will to prevent a financial setback from developing into a breakdown of the nation's entire economy.

Q: Will the bank's capital be decreased?

A: The measures to be adopted this time is utterly different from the one prescribed by the Article 102, 1, (3) of the Deposit Insurance Law, by which all its shares were acquired by the government, and consequently, the value of the other shareholders' equity was reduced to zero, like the case of the Long-Term Credit Bank of Japan. The measure to be taken this time is not nationalization but injection of public funds as a public support. There is absolutely no likelihood of decrease of the capital by decreasing the number of shares or by reducing the shareholders' right to zero as in the case of the Long-Term Credit Bank of Japan.

Q: Do you mean that there will be now partial decrease of the capital such as reduction of the number of shares?

A: Essentially, reduction of shareholders' responsibility by way of capital decrease is out of question.

Q: Please let us hear your view of the way of assuming managerial responsibility Resona decided on. Public funds were injected into the bank twice in the past. What do you think of the administrative responsibility for the necessity of the injection for the third time?

A: The present executive officers of the bank, I hear, will resign to take their responsibilities. [...] The combined total amount of remuneration and bonuses will be reduced about $30 \%$. We also hear that the number of the bank's affiliated companies will be practically halved. Other measures including appointment of younger executives and reduction of the number of executives will be taken for those companies. All such attempts at managerial reform are welcome. We feel regret over the need of public fund injection into the bank more than once in the past and the recent recurrence of the need. But the measure adopted this time is not intended for any failed or insolvent institution. Its objective is to assist the bank in its recovery. Since public funds will be injected to the bank, I expect that its executives

\footnotetext{
${ }^{36}$ It is worth comparing the answers formulated by the Minister for Financial Services Heizo Takenaka at the press conference that followed the inception of Resona's crisis to the excerpts from Todd Conover's Congressional testimony surrounding the Continental bailout reported by Kaufman (2002, Appendix A, p.434). While the contexts are different and the time frame separating the two bailouts spans over about twenty years, the key dilemmas behind the TBTF doctrine as well as the arguments favoring the use of taxpayers' money to resolve large bank failures are basically unchanged.
} 
will lead the bank successfully out of the present difficulties. We are to keep close watch over the bank from the standpoint of supervisors as well as inspectors.

Q: Whether injected public funds should be repaid or not is a controversial matter. Resona is not a failed or insolvent bank. Nor was it nationalized. I wonder whether giving away public money to a bank in need of support as if it were a subsidy is proper use of taxpayers' money.

A: As the Resona Bank is not a failed or insolvent financial institution, the measure to be taken this time is not compensation for the loss with public funds. Public funds will be injected this time on condition that they should be returned by a prefixed point in time in some way in principle - for example in the manner prescribed by the Early Strengthening of Financial Function Law. No time limit by which the injected funds must be recovered is fixed if common stock is acquired with the injected funds. But if the corporate value rises and the stock price rises accordingly, a surplus over the injected amount will be gained. Anyway, public funds are injected on condition that they should be recovered. 


\section{Appendix 3: A market-based measure of the probability of bank failure}

This appendix reminds the details of the basic calculations used to estimate the marketbased measure of the probability of failure, expressed in percentage, for each bank in our sample. The probabilistic approach to modelling bank failures has first proposed by Blair and Heggestad (1978). See also Koehn and Santomero (1980) for additional insights.

By definition, a bank failure occurs if the losses on the portfolio of assets erode the bank's capital base:

$$
\operatorname{Prob}\left\{\widetilde{x}<\mathbf{E}[\widetilde{x}]-k \sigma_{\widetilde{x}}\right\} \leq \frac{1}{k^{2}}
$$

where $\widetilde{x}$ designates the asset earnings. Following this approach, the bank is economically insolvent and fails when asset earnings fall $k$ standard deviations below $\mathbf{E}[\widetilde{x}]$ and, as a result, the economic capital $K$ becomes negative. The previous equation can be restated as:

$$
\operatorname{Prob}\left\{\frac{\widetilde{x}}{K}<\frac{\mathbf{E}[\widetilde{x}]-k \sigma_{\widetilde{x}}}{K}\right\} \leq \frac{1}{k^{2}}
$$

Taking into account that the failure is triggered when $\mathbf{E}[\widetilde{x}]-k \sigma_{\widetilde{x}}=-K$, we can re-write the probability of bank failure in the following way:

$$
\operatorname{Prob}\left\{\frac{\mathbf{E}[\widetilde{x}]}{K}<-1\right\} \leq\left(\frac{\sigma_{\widetilde{x}} / K}{1+\mathbf{E}[\widetilde{x}] / K}\right)^{2}
$$

This inequality implies that the probability of bank failure per unit of capital is an increasing function of the variance of asset earnings and a decreasing function of the expected value of asset earnings. From an empirical point of view, the probability of bank failure can thus be estimated using stock market data as the variance of equity log-returns over the estimation window divided by one plus the average equity return over the same window, squared:

$$
\text { Probability of failure }(\%)=\frac{\sigma_{R_{i}}^{2}}{\left(1+\bar{R}_{i}\right)^{2}} \times 100
$$




\section{References}

Bank for International Settlements (BIS) (2004) : "Bank Failures in Mature Economies", BIS Working Paper No. 3, April;

Berman, Dennis K. (2007) : "Can Banks Grow Too Big To Fail? Research Finds Lenders Would Pay More to Cross $\$ 100$ Billion Threshold", Wall Street Journal, December;

Billett, Matthew R., Jon A. Garfinkel, and Edward S. O'Neal (1998) : "The Cost of Market vs. Regulatory Discipline in Banking", Journal of Financial Economics, 48(3), pp. 333-358, June;

Blair, Roger D. and Arnold A. Heggestad (1978) : "Bank Portfolio Regulation and the Probability of Bank Failure: A Note", Journal of Money, Credit, and Banking, 10(1), pp. 8-93, February;

Bliss, Robert R. (2003) : "Bankruptcy Law and Large Complex Financial Organizations: A Primer", Federal Reserve Bank of Chicago, Economic Perspectives, 27(1), pp. 48-58, $1^{\text {st }}$ quarter;

Bremer, Marc et Richard H. Pettway (2002) : "Information and the Market's Perceptions of Japanese Bank Risk: Regulation, Environment, and Disclosure", Pacific-Basin Finance Journal, 10(2), pp. 119-139, April;

Brewer III, Elijah and Julapa Jagtiani (2007) : "How Much Would Banks Be Willing to Pay to Become "Too-Big-to-Fail" and to Capture Other Benefits?", Federal Reserve Bank of Kansas City, Research Working Paper No. 07-05, July;

Brewer III, Elijah, Hesna Genay, William Curt Hunter, and George G. Kaufman (2003) : "Does the Japanese Stock Market Price Bank-Risk? Evidence from Financial Firm Failures", Journal of Money, Credit, and Banking, 35(4), pp. 507-543, August;

Brown, Stephen J. and Jerold B. Warner (1985) : "Using Daily Stock Returns: The Case of Event Studies", Journal of Financial Economics, 14(1), pp. 3-31, March;

Corrado, Charles J. (1989) : "A Nonparametric Test for Abnormal Security-Price Performance in Event Studies", Journal of Financial Economics, 23(2), pp. 385-395, August;

Cowan, Arnold R. (1992) : "Nonparametric Event Study Tests", Review of Quantitative Finance and Accounting, 2(4), pp. 343-358, December;

Campbell, and Wasley (1996) : "Measuring Abnormal Daily Trading Volume for Samples of NYSE/ASE and NASDAQ Securities Using Parametric and Nonparametric Test Statistics", Review of Quantitative Finance and Accounting, 6(3), pp. 309-326, May;

De Bandt, Olivier and Philipp Hartmann (2002) : "Systemic Risk: A Survey", in "Financial Crises, Contagion, and the Lender of Last Resort: A Reader", Charles A.E. Goodhart and Gerhard Illing (eds.), Oxford University Press, pp. 249-298, January;

Flannery, Mark J. (2007) : "Supervising Bank Safety and Soundness: Some Open Issues", Federal Reserve Bank of Atlanta, Economic Review, 92(1-2), pp. 87-100, $1^{\text {st }}$ and $2^{\text {nd }}$ quarters;

Flannery, Mark J. and Sorin M. Sorescu (1996) : "Evidence of Bank Market Discipline in Subordinated Debentures Yields: 1983-1991", Journal of Finance, 51(4), pp. 1347-1377, September;

Fukao, Mitsuhiro (2004) : "Weakening Market and Regulatory Discipline in the Japanese Financial System", in "Market Discipline across Countries and Industries", Claudio Borio, William C. Hunter, George G. Kaufman, and Kostas Tsatsaronis (eds.), The MIT Press, Cambridge, MA, pp. 119-133;

Genay, Hesna (1999) : "Japanese Banks and Market Discipline", Federal Reserve Bank of Chicago, Chicago Fed Letter No. 144, August; 
Hancock, Diana and Myron L. Kwast (2001) : "Using Bond and Stock Markets to Monitor Bank Holdings Companies: Is It Feasible?", Journal of Financial Services Research, 20(2-3), pp. 147-187, October/December;

Hettmansperger, Thomas P. (1984) : "Statistical Inference Based on Ranks", New York: John Wiley;

Hoshi, Takeo and Anil K. Kashyap (2004) : "Japan's Financial Crisis and Economic Stagnation”, Journal of Economic Perspectives, 18(1), pp. 3-26, Winter;

Hull, John, Mirela Predescu, and Alan White (2004) : "The Relationship Between Credit Default Swap Spreads, Bond Yields, and Credit Rating Announcements", Journal of Banking and Finance, 28(11), pp. 2789-2811, November;

Imai, Masami (2006) : "Market Discipline and Deposit Insurance Reform in Japan", Journal of Banking and Finance, 30(12), pp. 3433-3452, December;

Jagtiani, Julapa A. and Catharine Lemieux (2001) : "Market Discipline Prior to Bank Failure", Journal of Economics and Business, 53(2-3), pp. 313-324, March/June;

Kaufman, George G. (2002) : “Too Big To Fail in US Banking: What Remains?”, Quarterly Review of Economics and Finance, 42(3), pp. 423-436, Autumn;

Kane, Edward J. (2000) : "Incentives for Banking Megamergers: What Motives Might Regulators Infer from Event-Study Evidence?", Journal of Money, Credit and Banking, 32(3), pp. 671-701, August;

Kim, Kenneth A. and S. Ghon Rhee (1997) : "Price Limit Performance: Evidence from the Tokyo Stock Exchange", Journal of Finance, 52(2), pp. 885-901, June;

Koehn, Michael and Anthony M. Santomero (1980) : "Regulation of Bank Capital and Portfolio Risk", Journal of Finance, 35(5), pp. 1235-1244, December;

Li, Joanne, Yoon S. Shin, and William T. Moore (2006) : "Reactions of Japanese Markets to Changes in Credit Ratings by Global and Local Agencies", Journal of Banking and Finance, 30(3), pp. 1007-1021, March;

Micu, Marian, Eli M. Remolona, and Philip D. Wooldridge (2004) : "The Price Impact of Rating Announcements: Evidence from the Credit Default Swap Market", BIS Quarterly Review, pp. 55-65, June;

Mishkin, Frederic S. (2006) : "How Big a Problem is Too Big To Fail? A Review of Gary Stern and Ron Feldman's Too Big to Fail: The Hazards of Bank Bailouts", Journal of Economic Literature, 44(4), pp. 988-1004, December;

Morgan, Donald P. and Kevin J. Stiroh (2005) : "Too Big to Fail After All These Years", Federal Reserve Bank of New York, Staff Report, No. 220, September;

Norden, Lars and Martin Weber (2004) : "Informational Efficiency of Credit Default Swap and Stock Markets: The Impact of Credit Rating Announcements", Journal of Banking and Finance, 28(11), pp. 2813-2843, November;

O'Hara, Maureen and Wayne Shaw (1990) : "Deposit Insurance and Wealth Effects: The Value of Being 'Too Big To Fail"', Journal of Finance, 45(5), pp. 1587-1660, December;

Penas, María Fabiana and Haluk Unal (2004) : "Gains in Bank Mergers: Evidence from the Bond Markets", Journal of Financial Economics, 74(1), pp. 149-179, November;

Pollin, Jean-Paul (2005) : "When Bank Regulators Meet the Dilemmas of 'Too-Big-To-Fail': Are There Viable Solutions?", University of Orleans, mimeo, August; 
Rime, Bertrand (2005) : “Do 'Too Big To Fail' Expectations Boost Large Banks Issuer Ratings?”, Swiss National Bank, mimeo, April;

Skinner, Douglas J. (2006) : "The Role of Deferred Tax Accounting in the Japanese Banking Crisis", University of Chicago, mimeo, July;

Spiegel, Mark M. and Nobuyoshi Yamori (2004) : "The Evolution of Bank Resolution Policies in Japan: Evidence from Market Equity Values", Journal of Financial Research, 27(1), pp. 115-132, Spring;

Stern, Gary H. et Ron J. Feldman (2004) : "Too Big To Fail: The Hazards of Bank Bailouts", Brookings Institution Press, Washington D.C.;

Swary, Itzhak (1986) : "Stock Market Reaction to Regulatory Action in the Continental Illinois Crisis", Journal of Business, 59(3), pp. 451-473, July;

van Rixtel, Adrian, Yupana Wiwattanakantang, Toshiyuki Souma, and Kazunori Suzuki (2004) : "Banking in Japan: Will Too Big To Fail Prevail?", in "Too-Big-To-Fail: Policies and Practices in Government Bailouts", Benton Gup (ed.), Westport, Conn.: Praeger;

Wall, Larry D. (1993) : "Too-Big-To-Fail After FDICIA", Federal Reserve Bank of Atlanta, Economic Review, 78, pp. 1-14, January/February;

Wall, Larry D. and David R. Peterson (1990) : "The Effect of Continental Illinois' Failure on the Financial Performance of Other Banks", Journal of Monetary Economics, 26(1), pp. 77-99, July.

Yamori, Nobuyoshi and Ayami Kobayashi (2007) : "Wealth Effect of Public Fund Injections to Ailing Banks: Do Deferred Tax Assets and Auditing Firms Matter?", Japanese Economic Review, 58(4), pp. 466483, December. 
Table 1

Beta coefficient estimates for the largest Japanese banks

\begin{tabular}{|c|c|c|c|c|c|c|c|c|}
\hline & \multicolumn{8}{|c|}{ TBTF2 Banks } \\
\hline & \multicolumn{5}{|c|}{ TBTF1 Banks } & \multirow{2}{*}{ MTH } & \multirow{2}{*}{ MTB } & \multirow{2}{*}{ STB } \\
\hline & MTFG & MFG & Resona & SMFG & UFJ & & & \\
\hline$\beta[-260 ;-11]$ & 1.353 & 1.897 & 1.266 & 1.775 & 2.031 & 1.400 & 1.577 & 1.882 \\
\hline $\mathrm{HO}: \beta=0$ & $12.71^{* * *}$ & $9.99^{* * *}$ & $10.31^{\star * *}$ & $11.31^{* * *}$ & $11.41^{* * *}$ & $9.33^{* * *}$ & $7.59^{\star \star *}$ & $15.77^{* * *}$ \\
\hline $\mathrm{H} 0: \beta=1$ & $11.01^{* * *}$ & $22.33^{\star * *}$ & $4.69^{* *}$ & $24.38^{* * *}$ & $33.53^{\star * *}$ & $7.11^{* * *}$ & $7.70^{\star \star *}$ & $54.65^{\star * *}$ \\
\hline $\mathrm{R} 2$ & 0.39 & 0.29 & 0.30 & 0.34 & 0.34 & 0.26 & 0.19 & 0.50 \\
\hline$\beta[-160 ;-11]$ & 1.371 & 2.257 & 1.270 & 1.928 & 2.488 & 1.526 & 1.565 & 1.970 \\
\hline $\mathrm{H} 0: \beta=0$ & $9.08^{* \star *}$ & $7.72^{\star \star \star}$ & $7.24^{\star \star \star}$ & $8.14^{\star \star \star}$ & $9.17^{\star \star \star}$ & $8.10^{\star \star \star}$ & $5.27^{\star \star \star}$ & $11.86^{* \star *}$ \\
\hline $\mathrm{HO}: \beta=1$ & $6.05^{\star *}$ & $18.46^{\star \star *}$ & $2.37^{*}$ & $15.36^{\star \star *}$ & $30.06^{\star * *}$ & $7.79^{\star \star \star}$ & $3.62^{*}$ & $34.11^{* * *}$ \\
\hline R2 & 0.36 & 0.29 & 0.26 & 0.31 & 0.36 & 0.31 & 0.16 & 0.49 \\
\hline
\end{tabular}

This table reports the beta coefficient for each of eight TBTF banks, estimated over two separate windows: [ $260 ;-$ $11]$ and [-160; -11]. T-statistics for the hypothesis that the reported coefficient equals zero (one) and a goodness of fit measure (R2) are also provided for each single-factor market model.

${ }^{* \star *},{ }^{* *}$, and ${ }^{*}$ indicate statistical significance at the $1 \%, 5 \%$, and $10 \%$ level, respectively 
Table 2

The "daily price limits" mechanism prevailing on TSE in 2003

\begin{tabular}{|c|c|}
\hline $\begin{array}{c}\text { Previous Day's Closing Price } \\
(x)\end{array}$ & $\begin{array}{l}\text { Daily Price Limit }( \pm) \\
(d p l)\end{array}$ \\
\hline$x<¥ 100$ & $¥ 30$ \\
\hline$¥ 100 \leq x<¥ 200$ & $¥ 50$ \\
\hline$¥ 200 \leq x<¥ 500$ & $¥ 80$ \\
\hline$¥ 500 \leq x<¥ 1,000$ & $¥ 100$ \\
\hline$¥ 1,000 \leq x<¥ 1,500$ & $¥ 200$ \\
\hline$¥ 1,500 \leq x<¥ 2,000$ & $¥ 300$ \\
\hline$¥ 2,000 \leq x<¥ 3,000$ & $¥ 400$ \\
\hline$¥ 3,000 \leq x<¥ 5,000$ & $¥ 500$ \\
\hline$¥ 5,000 \leq x<¥ 10,000$ & $¥ 1,000$ \\
\hline$¥ 10,000 \leq x<¥ 20,000$ & $¥ 2,000$ \\
\hline$¥ 20,000 \leq x<¥ 30,000$ & $¥ 3,000$ \\
\hline$¥ 30,000 \leq x<¥ 50,000$ & $¥ 4,000$ \\
\hline$¥ 50,000 \leq x<¥ 70,000$ & $¥ 5,000$ \\
\hline$¥ 70,000 \leq x<¥ 100,000$ & $¥ 10,000$ \\
\hline$¥ 100,000 \leq x<¥ 150,000$ & $¥ 20,000$ \\
\hline$¥ 150,000 \leq x<¥ 200,000$ & $¥ 30,000$ \\
\hline$¥ 200,000 \leq x<¥ 300,000$ & $¥ 40,000$ \\
\hline$¥ 300,000 \leq x<¥ 500,000$ & $¥ 50,000$ \\
\hline$¥ 500,000 \leq x<¥ 1,000,000$ & $¥ 100,000$ \\
\hline$¥ 1,000,000 \leq x<¥ 1,500,000$ & $¥ 200,000$ \\
\hline$¥ 1,500,000 \leq x<¥ 2,000,000$ & $¥ 300,000$ \\
\hline$¥ 2,000,000 \leq x<¥ 3,000,000$ & $¥ 400,000$ \\
\hline$¥ 3,000,000 \leq x<¥ 5,000,000$ & $¥ 500,000$ \\
\hline$¥ 5,000,000 \leq x<¥ 10,000,000$ & $¥ 1,000,000$ \\
\hline$¥ 10,000,000 \leq x<¥ 15,000,000$ & $¥ 2,000,000$ \\
\hline$¥ 15,000,000 \leq x<¥ 20,000,000$ & $¥ 3,000,000$ \\
\hline$¥ 20,000,000 \leq x<¥ 30,000,000$ & $¥ 4,000,000$ \\
\hline$¥ 30,000,000 \leq x<¥ 50,000,000$ & $¥ 5,000,000$ \\
\hline$¥ 50,000,000 \leq x$ & $¥ 10,000,000$ \\
\hline
\end{tabular}

Source: Tokyo Stock Exchange (TSE) 
Table 3

Stock price pressures and order flow imbalances following Resona's bailout

\begin{tabular}{|c|c|c|c|c|c|}
\hline & $\begin{array}{l}\text { Full Sample } \\
\qquad(N=93)\end{array}$ & $\begin{array}{c}\text { TBTF1 Banks } \\
(N=5)\end{array}$ & $\begin{array}{c}\text { Non-TBTF1 } \\
\text { Banks } \\
(N=88)\end{array}$ & $\begin{array}{c}\text { TBTF2 Banks } \\
(N=8)\end{array}$ & $\begin{array}{c}\text { Non-TBTF2 } \\
\text { Banks } \\
(N=85)\end{array}$ \\
\hline \multicolumn{6}{|l|}{ Downward Price Movements } \\
\hline Down-limit hits [day 0] & 1 & 1 & 0 & 1 & 0 \\
\hline Near down-limit hits [day 0] & 6 & 3 & 3 & 3 & 3 \\
\hline \multicolumn{6}{|l|}{ Upward Price Movements } \\
\hline Up-limit hits [day +2] & 2 & 2 & 0 & 2 & 0 \\
\hline Near up-limit hits [day +2$]$ & 8 & 4 & 4 & 4 & 4 \\
\hline \multicolumn{6}{|l|}{ Order Flow Imbalances } \\
\hline Quotes at the Bid [day 0] & 39 & 3 & 36 & 6 & 33 \\
\hline Quotes at the Ask [day +2] & 18 & 4 & 14 & 5 & 13 \\
\hline Order Flow Ratio \% [day 0] & $64.9(65.9)$ & $60.0(100.0)$ & $65.2(75.0)$ & $75.0(100.0)$ & $63.9(75.0)$ \\
\hline Order Flow Ratio $\%$ [day +2$]$ & $65.9(90.9)$ & $20.0(0.0)^{\dagger}$ & $68.8(100.0)^{\dagger}$ & $37.5(0.0)^{\ddagger}$ & $68.9(100.0)^{\ddagger}$ \\
\hline
\end{tabular}

The table presents several microstructure variables helping to identify systematic order flow patterns and price pressures around the bailout announcement date. "Down(Up)-limit hits" takes the value of 1 if a bank stock price reaches the downward (upward) daily price limit and 0 otherwise. Similarly, "Near down(up)-limit hits" is equal to 1 for bank stocks that experience price changes of at least $90 \%$ of the daily limit. The "order flow ratio," expressed in \%, is calculated as (Closing Ask - Closing Price)/(Closing Ask - Closing Bid)×100 (the reported numbers are mean (median) values, calculated separately for the five samples).

${ }^{\dagger}$ The order flow ratio is significantly lower in the TBTF1 sample than in the non-TBTF1 sample according to the mean test $(t=2.64, p<0.01)$ and median tests (Wilcoxon-Mann-Whitney statistic $=2.09, p<0.05$; Kruskal-Wallis statistic $=4.42, p<0.05$ )

${ }^{\ddagger}$ The order flow ratio is significantly lower in the TBTF2 sample than in the non-TBTF2 sample according to the mean test $(t=2.08, p<0.05)$ and median tests (Wilcoxon-Mann-Whitney statistic $=1.65, p<0.1$; Kruskal-Wallis statistic $=2.76, p<0.1)$ 


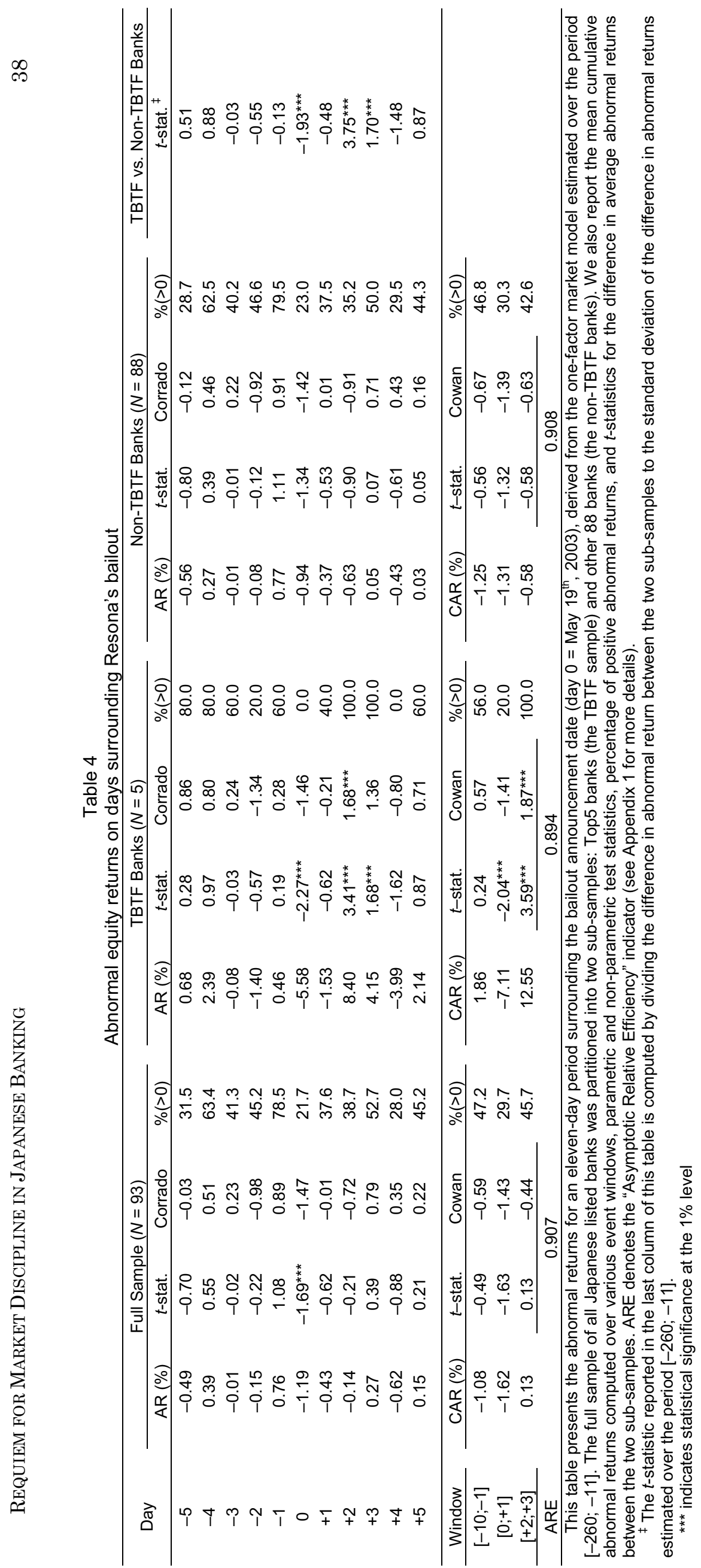




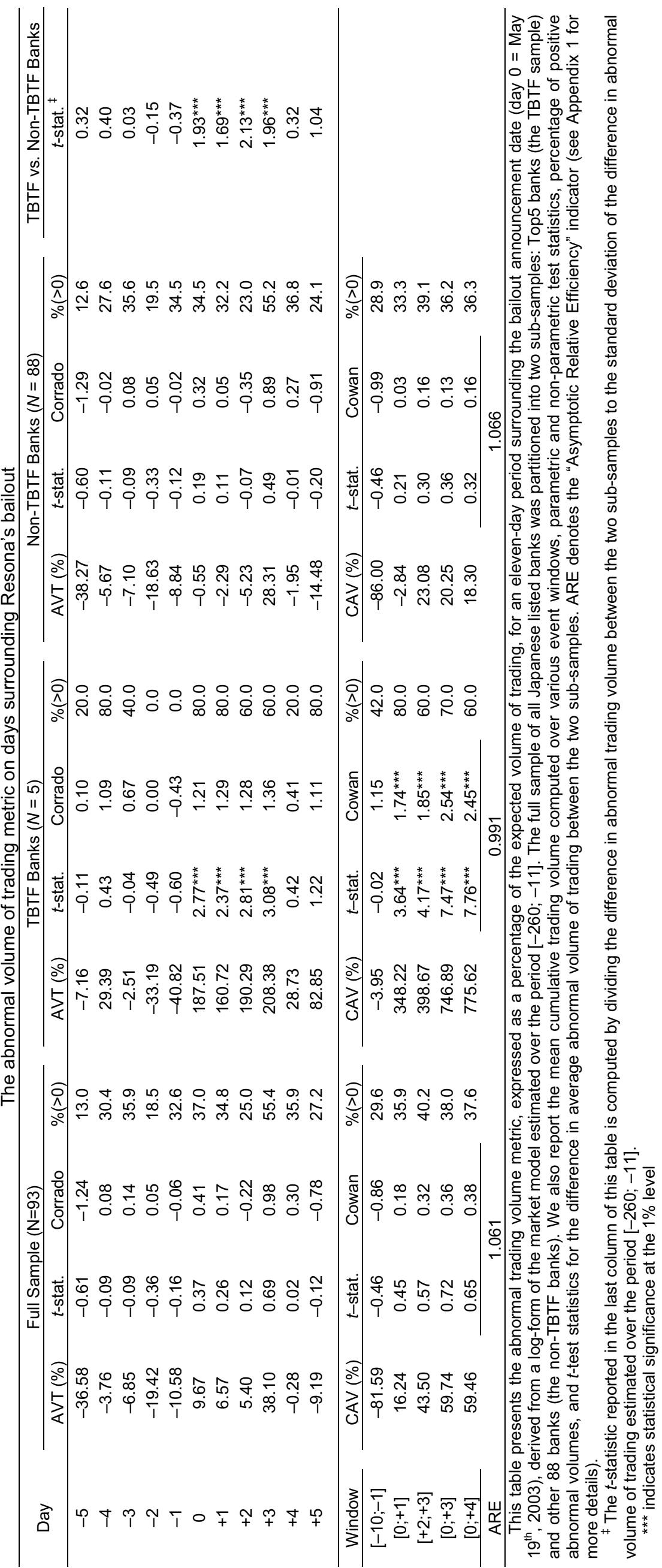


Table 6

A bivariate comparison of risk, profitability, and bank capitalization measures across various sub-samples

\begin{tabular}{|c|c|c|c|c|c|c|c|}
\hline Variable & $\begin{array}{c}\begin{array}{c}\text { Global } \\
(N=93)\end{array} \\
\text { Mean } \\
\text { (Median) }\end{array}$ & $\begin{array}{c}\text { TBTF1 } \\
(N=5) \\
\text { Mean } \\
\text { (Median) }\end{array}$ & & $\begin{array}{c}\text { Non-TBTF1 } \\
(N=88) \\
\text { Mean } \\
\text { (Median) }\end{array}$ & $\begin{array}{c}\text { TBTF2 } \\
(N=8) \\
\text { Mean } \\
\text { (Median) }\end{array}$ & & $\begin{array}{c}\text { Non-TBTF2 } \\
(N=85) \\
\text { Mean } \\
\text { (Median) }\end{array}$ \\
\hline \multicolumn{8}{|l|}{ Risk measures } \\
\hline Probability of Failure $(\%)$ & $\begin{array}{c}4.71 \\
(3.27)\end{array}$ & $\begin{array}{c}15.72 \\
(16.62)\end{array}$ & $\begin{array}{l}>> \\
>>\end{array}$ & $\begin{array}{c}4.08 \\
(3.17)\end{array}$ & $\begin{array}{c}16.00 \\
(15.01)\end{array}$ & $\begin{array}{l}>> \\
>>\end{array}$ & $\begin{array}{c}3.64 \\
(3.14)\end{array}$ \\
\hline NCO / Average Gross Loans (\%) & $\begin{array}{c}0.11 \\
(0.00)\end{array}$ & $\begin{array}{c}0.79 \\
(0.83)\end{array}$ & $\begin{array}{l}>> \\
>>\end{array}$ & $\begin{array}{c}0.06 \\
(0.00)\end{array}$ & $\begin{array}{c}0.58 \\
(0.28)\end{array}$ & $\begin{array}{l}>> \\
>>\end{array}$ & $\begin{array}{c}0.06 \\
(0.00)\end{array}$ \\
\hline $\begin{array}{l}\text { Loan Loss Prov / Net Int Rev (\%) } \\
\text { Credit ratings }\end{array}$ & $\begin{array}{c}27.21 \\
(19.01)\end{array}$ & $\begin{array}{c}89.61 \\
(51.66)\end{array}$ & $\begin{array}{l}> \\
>\end{array}$ & $\begin{array}{c}23.41 \\
(18.75)\end{array}$ & $\begin{array}{l}65.63 \\
(30.45)\end{array}$ & $\begin{array}{l}> \\
>\end{array}$ & $\begin{array}{c}23.32 \\
(18.75)\end{array}$ \\
\hline Global Raters (Moody's, S\&P) & $\begin{array}{c}8.87 \\
(9.00)\end{array}$ & $\begin{array}{c}8.43 \\
(8.17)\end{array}$ & & $\begin{array}{c}8.91 \\
(9.00)\end{array}$ & $\begin{array}{c}8.96 \\
(8.38)\end{array}$ & & $\begin{array}{c}8.85 \\
(9.00)\end{array}$ \\
\hline Local Rating Agencies (JCR, R\&l) & $\begin{array}{c}5.73 \\
(6.00)\end{array}$ & $\begin{array}{c}6.18 \\
(6.25)\end{array}$ & & $\begin{array}{l}5.68 \\
(6.00)\end{array}$ & $\begin{array}{c}6.61 \\
(6.63)\end{array}$ & & $\begin{array}{c}5.58 \\
(6.00)\end{array}$ \\
\hline Moody's Financial Strength & $\begin{array}{c}10.19 \\
(10.00)\end{array}$ & $\begin{array}{c}12.53 \\
(13.00)\end{array}$ & $\begin{array}{l}>> \\
>>\end{array}$ & $\begin{array}{c}9.80 \\
(10.00)\end{array}$ & $\begin{array}{c}12.38 \\
(12.66)\end{array}$ & $\begin{array}{l}>> \\
>>\end{array}$ & $\begin{array}{c}9.64 \\
(10.00)\end{array}$ \\
\hline \multicolumn{8}{|l|}{ Profitability } \\
\hline $\mathrm{ROA}(\%)$ & $\begin{array}{c}0.13 \\
(0.22)\end{array}$ & $\begin{array}{l}-0.67 \\
(0.35)\end{array}$ & $<<$ & $\begin{array}{c}0.17 \\
(0.21)\end{array}$ & $\begin{array}{l}-0.25 \\
(0.38)\end{array}$ & $<$ & $\begin{array}{c}0.16 \\
(0.21)\end{array}$ \\
\hline Net Interest Rev / Avg Assets (\%) & $\begin{array}{c}1.64 \\
(1.62)\end{array}$ & $\begin{array}{c}1.14 \\
(1.05)\end{array}$ & $\begin{array}{l}<< \\
<<\end{array}$ & $\begin{array}{c}1.67 \\
(1.65)\end{array}$ & $\begin{array}{c}0.97 \\
(0.97)\end{array}$ & $\begin{array}{l}<< \\
<<\end{array}$ & $\begin{array}{c}1.70 \\
(1.67)\end{array}$ \\
\hline Net Interest Margin (\%) & $\begin{array}{c}1.71 \\
(1.68)\end{array}$ & $\begin{array}{c}1.20 \\
(1.11)\end{array}$ & $\begin{array}{l}<< \\
<<\end{array}$ & $\begin{array}{c}1.74 \\
(1.71)\end{array}$ & $\begin{array}{c}1.03 \\
(1.02)\end{array}$ & $\begin{array}{l}<< \\
<<\end{array}$ & $\begin{array}{c}1.77 \\
(1.72)\end{array}$ \\
\hline \multicolumn{8}{|l|}{ Bank capitalization } \\
\hline Equity / Total Assets (\%) & $\begin{array}{c}4.95 \\
(4.93)\end{array}$ & $\begin{array}{c}3.43 \\
(3.43)\end{array}$ & $\begin{array}{l}< \\
<\end{array}$ & $\begin{array}{c}5.03 \\
(5.00)\end{array}$ & $\begin{array}{c}4.13 \\
(4.01)\end{array}$ & $<$ & $\begin{array}{c}5.03 \\
(4.98)\end{array}$ \\
\hline Market Leverage (\%) & $\begin{array}{c}35.66 \\
(33.74)\end{array}$ & $\begin{array}{c}83.11 \\
(85.43)\end{array}$ & $\begin{array}{l}>> \\
>>\end{array}$ & $\begin{array}{c}32.62 \\
(32.94)\end{array}$ & $\begin{array}{c}77.20 \\
(75.82)\end{array}$ & $\begin{array}{l}>> \\
>>\end{array}$ & $\begin{array}{c}31.23 \\
(32.61)\end{array}$ \\
\hline Deferred Tax Assets / Equity (\%) & $\begin{array}{c}22.88 \\
(17.48)\end{array}$ & $\begin{array}{c}42.60 \\
(36.91)\end{array}$ & $>>$ & $\begin{array}{c}21.76 \\
(16.75)\end{array}$ & $\begin{array}{c}39.22 \\
(36.58)\end{array}$ & $>>$ & $\begin{array}{c}21.35 \\
(16.33)\end{array}$ \\
\hline \multicolumn{8}{|l|}{ Other variables } \\
\hline Turnover $(\%)$ & $\begin{array}{c}0.11 \\
(0.04)\end{array}$ & $\begin{array}{c}1.05 \\
(1.01)\end{array}$ & $\begin{array}{l}>> \\
>>\end{array}$ & $\begin{array}{c}0.06 \\
(0.04)\end{array}$ & $\begin{array}{c}0.74 \\
(0.68)\end{array}$ & $\begin{array}{l}>> \\
>>\end{array}$ & $\begin{array}{c}0.05 \\
(0.03)\end{array}$ \\
\hline Total Assets (US\$ billions) & $\begin{array}{c}77.48 \\
(23.82)\end{array}$ & $\begin{array}{c}852.00 \\
(950.00)\end{array}$ & $\begin{array}{l}>> \\
>>\end{array}$ & $\begin{array}{c}33.48 \\
(23.07)\end{array}$ & $\begin{array}{c}576.00 \\
(517.00)\end{array}$ & $\begin{array}{l}>> \\
>>\end{array}$ & $\begin{array}{c}30.53 \\
(22.29)\end{array}$ \\
\hline Bid-Ask Spread (\%) & $\begin{array}{c}1.16 \\
(0.65)\end{array}$ & $\begin{array}{c}0.77 \\
(0.52)\end{array}$ & & $\begin{array}{c}1.18 \\
(0.68)\end{array}$ & $\begin{array}{c}0.71 \\
(0.49)\end{array}$ & & $\begin{array}{c}1.20 \\
(0.70)\end{array}$ \\
\hline Intraday Max Range (\%) & $\begin{array}{c}2.32 \\
(1.79)\end{array}$ & $\begin{array}{c}6.40 \\
(3.98)\end{array}$ & $\begin{array}{l}>> \\
>>\end{array}$ & $\begin{array}{c}2.09 \\
(1.64)\end{array}$ & $\begin{array}{c}5.61 \\
(4.04)\end{array}$ & $\begin{array}{l}>> \\
>>\end{array}$ & $\begin{array}{c}2.01 \\
(1.62)\end{array}$ \\
\hline Free Float $(\%)$ & $\begin{array}{c}86.69 \\
(87.00)\end{array}$ & $\begin{array}{c}89.60 \\
(88.00)\end{array}$ & & $\begin{array}{c}86.52 \\
(87.00)\end{array}$ & $\begin{array}{c}90.63 \\
(92.00)\end{array}$ & $>$ & $\begin{array}{c}86.32 \\
(87.00)\end{array}$ \\
\hline
\end{tabular}

This table presents several key financial variables measuring three dimensions of the banking performance (risk, profitability, and capitalization), cardinalized credit ratings, and other control variables (mean and median values) calculated separately for the full sample and various sub-samples of banks. The credit ratings are converted to cardinal values according to the following scales: $\mathrm{AAA} / \mathrm{Aaa}=1, \mathrm{~A} A+/ \mathrm{Aa} 1=2, \mathrm{AA} / \mathrm{Aa} 2=3, \ldots, \mathrm{B} / \mathrm{B}=15$ (traditional ratings); $\mathrm{A}=1, \mathrm{~A}=2, \mathrm{~B}+=3, \ldots, \mathrm{E}=13$ (financial strength ratings). Hence, a lower cardinal value corresponds to a higher credit quality. See text for the definition of variables.

$>>(<<)$ and $>(<)$ indicate that the left-hand value is greater (lower) than the right-hand value at the $1 \%$ and $5 \%$ level, respectively, according to the mean $t$-test and median tests (Wilcoxon-Mann-Whitney and Kruskal-Wallis) 
Table 7

Correlation coefficients between abnormal returns (trading volumes) and various bank performance variables

\begin{tabular}{|c|c|c|c|c|c|c|}
\hline \multirow{2}{*}{ Variable } & \multirow{2}{*}{$N$} & \multicolumn{2}{|c|}{ SCAR } & \multicolumn{3}{|c|}{ SCAVT } \\
\hline & & {$[0 ;+1]$} & {$[+2 ;+3]$} & {$[0 ;+1]$} & {$[+2 ;+3]$} & {$[0 ;+3]$} \\
\hline \multicolumn{7}{|l|}{ Risk measures } \\
\hline Probability of Failure $(\%)$ & 93 & $-0.309^{* \star *}$ & $0.345^{\star * *}$ & $0.172^{*}$ & 0.117 & 0.147 \\
\hline NCO / Average Gross Loans (\%) & 84 & $-0.371^{* \star *}$ & $0.513^{* * *}$ & $0.588^{* * \star}$ & $0.591^{\star \star \star}$ & $0.604^{\star * \star}$ \\
\hline Loan Loss Prov / Net Int Rev (\%) & 87 & $-0.287^{\star * *}$ & $0.439^{* * *}$ & $0.539 * * *$ & $0.542^{* * *}$ & $0.554^{* * *}$ \\
\hline \multicolumn{7}{|l|}{ Credit ratings } \\
\hline Global Raters (Moody's, S\&P) & 56 & -0.211 & 0.101 & 0.142 & 0.127 & 0.136 \\
\hline Local Rating Agencies (JCR, R\&I) & 57 & $-0.409^{* \star *}$ & 0.210 & $0.269^{* * *}$ & $0.246^{\star \star}$ & $0.261^{* *}$ \\
\hline Moody's Financial Strength & 35 & $-0.627^{* * *}$ & $0.429^{\star * *}$ & 0.254 & $0.288^{*}$ & 0.275 \\
\hline \multicolumn{7}{|l|}{ Profitability } \\
\hline $\mathrm{ROA}(\%)$ & 93 & $0.274^{\star * *}$ & $-0.549^{\star * \star}$ & $-0.779^{\star * *}$ & $-0.778^{* * *}$ & $-0.798^{* * *}$ \\
\hline Net Int Rev / Avg Assets (\%) & 92 & 0.042 & $-0.225^{\star \star}$ & -0.125 & -0.046 & -0.086 \\
\hline Net Interest Margin (\%) & 92 & $0.237^{* *}$ & $-0.330^{\star * \star}$ & $-0.320^{\star * *}$ & $-0.316^{\star * *}$ & $-0.326^{\star * *}$ \\
\hline \multicolumn{7}{|l|}{ Bank Capitalization } \\
\hline Equity / Total Assets (\%) & 93 & 0.101 & -0.159 & $-0.240^{* *}$ & $-0.190^{*}$ & $-0.219^{* *}$ \\
\hline Market Leverage (\%) & 83 & $-0.311^{* \star *}$ & $0.297^{* * *}$ & 0.176 & 0.171 & $0.178^{*}$ \\
\hline Deferred Tax Assets / Equity (\%) & 93 & $-0.178^{*}$ & 0.091 & 0.054 & 0.050 & 0.053 \\
\hline \multicolumn{7}{|l|}{ Other control variables } \\
\hline Turnover $(\%)$ & 93 & $-0.461^{* * *}$ & $0.712^{\star * \star}$ & $0.741^{* * *}$ & $0.724^{\star * \star}$ & $0.745^{\star * *}$ \\
\hline Log Size & 93 & $-0.239^{\star \star}$ & $0.410^{* * *}$ & $0.250^{\star *}$ & $0.233^{\star *}$ & $0.247^{* *}$ \\
\hline Bid-Ask Spread (\%) & 92 & -0.020 & -0.132 & 0.060 & 0.140 & 0.105 \\
\hline Intraday Max Range (\%) & 93 & $-0.525^{\star * *}$ & $0.442^{\star * *}$ & $0.686^{* * *}$ & $0.717^{\star * *}$ & $0.720^{* * *}$ \\
\hline Free Float (\%) & 93 & -0.129 & 0.120 & 0.119 & 0.095 & 0.109 \\
\hline TBTF1 Dummy & 93 & $-0.286^{\star * *}$ & $0.592^{\star * *}$ & $0.431^{* * *}$ & $0.433^{\star * *}$ & $0.443^{* * *}$ \\
\hline TBTF2 Dummy & 93 & $-0.358^{* * *}$ & $0.561^{* * *}$ & $0.388^{* * *}$ & $0.336^{* * *}$ & $0.370^{* * *}$ \\
\hline
\end{tabular}

This table presents correlation coefficients between standardized cumulative abnormal returns (SCAR) and standardized cumulative abnormal volume of trading (SCAVT), on the one side, and several key financial variables measuring three dimensions of the banking performance (risk, profitability, and capitalization), cardinalized credit ratings, and other control variables, on the other side. SCAR and SCAVT are computed over various post-event windows $([0 ;+1],[+2 ;+3],[0 ;+3])$ in order to take into account the wide swing detected in stock market prices for the largest banks. The credit ratings are converted to cardinal values according to the following scales: $A A A / A a a=1, A A+/ A a 1=2, A A / A a 2=3, \ldots, B / B=15$ (traditional ratings); $A=1, A=2, B+=3, \ldots, E=13$ (financial strength ratings). Hence, a lower cardinal value corresponds to a higher credit quality. See text for the definition of variables.

${ }^{* * *},{ }^{* *}$, and * indicate statistical significance at the $1 \%, 5 \%$, and $10 \%$ level, respectively 


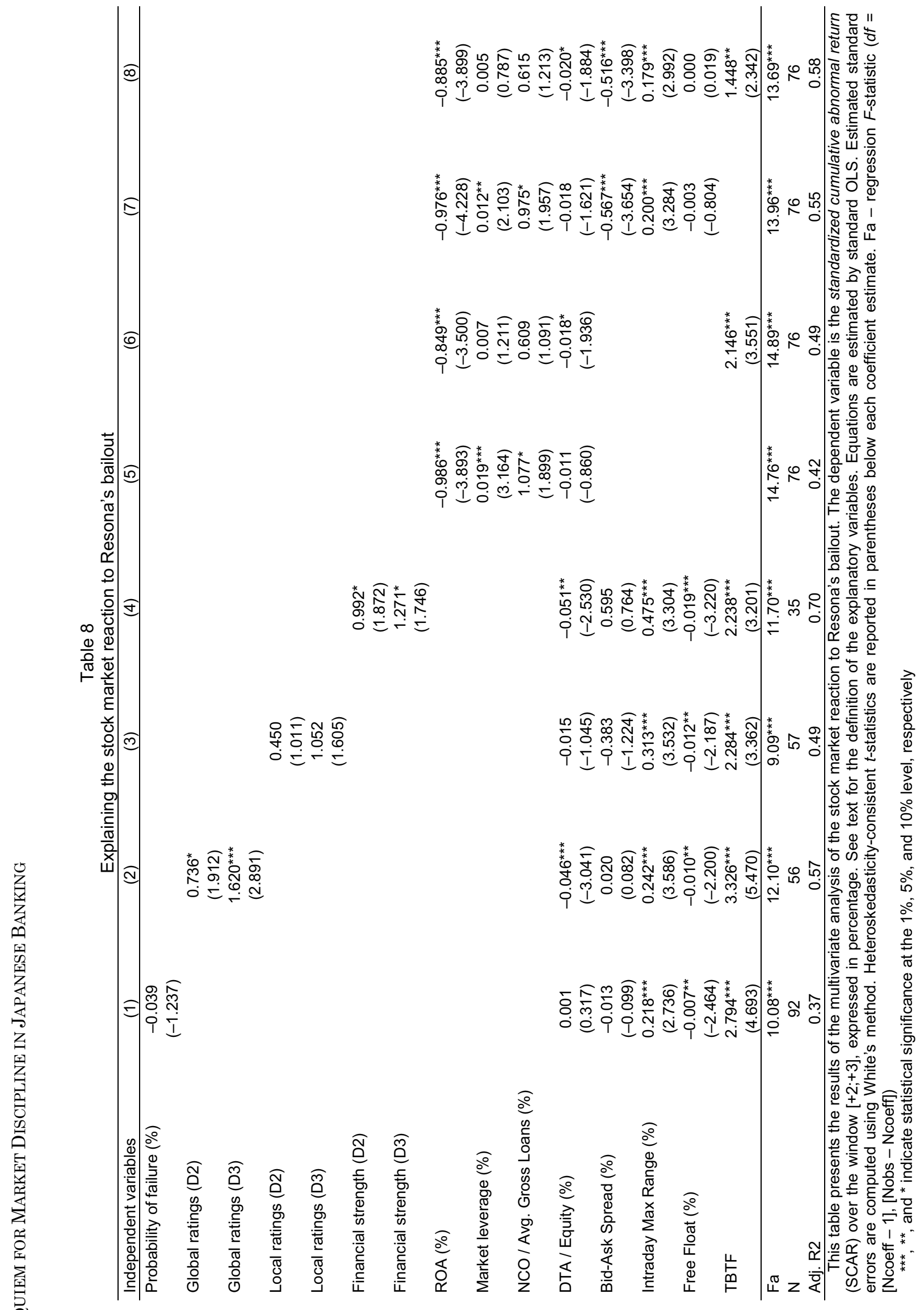


Table 9

List of financial obligors included in MarkIT and CMA Credit Default Swap samples

\begin{tabular}{|c|c|c|c|c|}
\hline No & Reference Entity & Credit Rating & MarkIT Sample & CMA Sample \\
\hline 1 & Acom Co Ltd & A & Yes & Yes \\
\hline 2 & Aiful Corp & BBB & Yes & Yes \\
\hline 3 & Aioi Insurance Co Ltd & $A$ & Yes & No \\
\hline 4 & Bank of Fukuoka Ltd & BBB & Yes & No \\
\hline 5 & Bank of Tokyo Mitsubishi Ltd & $A$ & Yes & No \\
\hline 6 & Bank of Yokohama Ltd & $A$ & Yes & No \\
\hline 7 & Credit Saison Co Ltd & $A$ & Yes & Yes* \\
\hline 8 & Daiwa Securities Group Inc & BBB & Yes & Yes \\
\hline 9 & Hankyu Hanshin Holding Inc & NR & No & Yes \\
\hline 10 & Hiroshima Bank Ltd & BBB & Yes & No \\
\hline 11 & Hitachi Capital Corp & $A$ & Yes & Yes* \\
\hline 12 & Millea Holdings Inc & AA & Yes & No \\
\hline 13 & Mitsubishi Estate Co Ltd & $A$ & Yes & Yes \\
\hline 14 & Mitsubishi UFJ Financial Group Inc & BBB & No & Yes \\
\hline 15 & Mitsui Fudosan Co Ltd & $A$ & Yes & Yes \\
\hline 16 & Mitsui Sumitomo Insurance Co Ltd & AA & Yes & Yes \\
\hline 17 & Mizuho Bank Ltd & AA & Yes & Yes* \\
\hline 18 & Mizuho Holdings Inc & BBB & Yes & No \\
\hline 19 & Nikko Cordial Corp & BBB & Yes & Yes \\
\hline 20 & Nikko Cordial Securities Inc & BBB & Yes & No \\
\hline 21 & Nomura Holdings Inc & BBB & Yes & Yes \\
\hline 22 & Nomura Securities Co Ltd & $A$ & Yes & Yes $^{*}$ \\
\hline 23 & Norinchukin Bank & AA & Yes & Yes $^{*}$ \\
\hline 24 & Orix Corp & BBB & Yes & Yes \\
\hline 25 & Promise Co Ltd & $A$ & Yes & Yes \\
\hline 26 & Resona Bank Ltd & BB & No & Yes* \\
\hline 27 & Sagami Rwy Co Ltd & BB & Yes & $\mathrm{Yes}^{\dagger}$ \\
\hline 28 & Sanyo Elec Cr Co Ltd & $\mathrm{AA}$ & Yes & Yes $^{\star \dagger}$ \\
\hline 29 & Sanyo Shinpan Fin Co & BBB & No & Yes* \\
\hline 30 & Shiga Bank Ltd & BBB & Yes & No \\
\hline 31 & Shinkin Central Bank & AA & Yes & No \\
\hline 32 & Shinsei Bank Ltd & BBB & No & Yes $^{*}$ \\
\hline 33 & Sompo Japan Ins Inc & AA & Yes & Yes \\
\hline 34 & Sumitomo Mitsui Finl Gp Inc & $A$ & Yes & No \\
\hline 35 & Sumitomo Mitsui Bkg Corp & BBB & No & Yes \\
\hline 36 & Sumitomo $\operatorname{Tr} \&$ Bkg Co Ltd & BBB & No & No \\
\hline 37 & Takefuji Corp & BBB & Yes & Yes \\
\hline 38 & UFJ Bank Ltd & A & Yes & $\mathrm{Yes}^{\dagger}$ \\
\hline
\end{tabular}

* No data available on May $19^{\text {th }}, 2003$ (i.e. the "event date")

${ }^{\dagger}$ The veracity score is higher than 4 indicating that the CDS spread is derived NB: Banking organizations are represented in italics 
Table 10

Panel A: CDS market reaction to the announcement of Resona's bailout (CMA sample)

\begin{tabular}{lccccccc}
\hline \multicolumn{1}{c}{ CMA sample } & day 0 & day +1 & day +2 & day +3 & day +4 & {$[0 ;+4]$} & {$[-3 ;-1]$} \\
\hline Acom Co Ltd & -36.12 & 1.51 & -0.76 & 1.36 & -1.61 & -35.62 & $-2,01$ \\
Aiful Corp & -47.00 & -1.61 & 4.38 & -3.42 & 2.16 & -45.49 & $-3,43$ \\
Mitsubishi UFJ Fin Gp Inc & -4.60 & 0.00 & 0.00 & 4.03 & 0.00 & -0.57 & 1,56 \\
Daiwa Securities Gp Inc & -0.68 & 1.66 & -0.83 & 1.49 & -1.76 & -0.12 & $-0,71$ \\
Hitachi Capital Corp & -12.47 & 0.00 & 0.00 & 3.56 & 4.84 & -4.07 & 0,00 \\
Hankyu Hanshin Hdg Inc & 8.74 & -1.55 & 4.20 & -3.28 & 2.08 & 10.19 & $-2,29$ \\
Mitsui Sumitomo Ins Co Ltd & -9.23 & 0.00 & 0.00 & 3.90 & -5.96 & -11.29 & 0,00 \\
Nikko Cordial Corp & 39.91 & 1.66 & -0.83 & 1.49 & -1.76 & 40.47 & $-4,54$ \\
Nomura Holdings Inc & -46.95 & 0.00 & 0.00 & 4.83 & 0.00 & -42.12 & $-0,78$ \\
Orix Corp & -2.22 & -1.25 & 3.39 & -2.65 & 1.67 & -1.06 & $-2,01$ \\
Promise Co Ltd & 40.20 & 1.34 & -0.68 & 1.21 & -1.42 & 40.65 & 0,00 \\
Sumitomo Mitsui Bkg Corp & -65.24 & 0.37 & -0.18 & 0.33 & -0.39 & -65.11 & $-0,71$ \\
Takefuji Corp & -29.67 & 0.00 & 0.00 & 0.00 & 0.00 & -29.67 & 0,46 \\
Sompo Japan Ins Inc & 0.00 & 0.00 & 0.00 & 0.00 & 0.00 & 0.00 & 0,00 \\
Mitsui Fudosan Co Ltd & -68.53 & 1.04 & -0.52 & 0.93 & -1.10 & -68.18 & $-2,10$ \\
Mitsubishi Estate Co Ltd & -48.79 & 5.37 & 0.00 & -5.32 & -0.04 & -48.78 & $-3,50$ \\
\hline \multicolumn{1}{c}{$\quad$ All entities } & $-42.46^{* * *}$ & 3.44 & -0.38 & -1.98 & -0.82 & $-42.20^{* * *}$ & $-2,76$ \\
$\quad$ & $(-8.42)$ & $(0.68)$ & $(-0.08)$ & $(-0.39)$ & $(-0.16)$ & $(-8.37)$ & $(-0,55)$ \\
\hline
\end{tabular}

Panel B: CDS market reaction to the announcement of Resona's bailout (MarkIT sample)

\begin{tabular}{|c|c|c|c|c|c|c|c|}
\hline MarkIT sample & day 0 & day +1 & day +2 & day +3 & day +4 & {$[0 ;+4]$} & {$[-3 ;-1]$} \\
\hline Acom Co Ltd & 0.00 & 0.00 & 0.67 & -7.67 & 0.00 & -7.00 & -3.34 \\
\hline Aiful Corp & -6.25 & 1.25 & -9.16 & 0.00 & 0.00 & -14.16 & 1.44 \\
\hline Bank of Fukuoka Ltd & 0.00 & 0.00 & 0.00 & 0.00 & 0.00 & 0.00 & 0.00 \\
\hline Bank of Yokohama Ltd & 0.00 & 0.00 & 0.00 & 0.00 & 0.00 & 0.00 & 0.00 \\
\hline Daiwa Securities Gp Inc & -1.67 & 0.00 & 0.00 & -3.25 & 6.11 & 1.19 & 18.62 \\
\hline Hitachi Capital Corp & 0.00 & 0.00 & 0.00 & 0.00 & 0.00 & 0.00 & -35.83 \\
\hline Mitsubishi Estate Co Ltd & 0.00 & -0.78 & 0.00 & 0.99 & 0.00 & 0.21 & 0.42 \\
\hline Mitsui Fudosan Co Ltd & 2.15 & 6.84 & 10.48 & -6.78 & 0.00 & 12.69 & -4.11 \\
\hline Mizuho Bank Ltd & 0.00 & 0.00 & 0.00 & 0.00 & 0.00 & 0.00 & 5.63 \\
\hline Bank of Tokyo Mitsubishi Ltd & -6.42 & 0.00 & 6.28 & -5.15 & -0.32 & -5.62 & 0.00 \\
\hline Nikko Cordial Corp & 30.00 & 0.00 & -34.58 & 1.41 & 0.00 & -3.17 & -1.25 \\
\hline Nomura Holdings Inc & 0.00 & 0.00 & 0.00 & 0.00 & 0.00 & 0.00 & 0.00 \\
\hline Nomura Securities Co Ltd & 0.00 & 0.00 & 0.00 & 7.33 & -6.99 & 0.35 & 1.45 \\
\hline Orix Corp & 0.00 & 0.00 & 0.00 & -3.67 & 0.00 & -3.67 & -7.59 \\
\hline Promise Co Ltd & -0.45 & 0.00 & 0.00 & 0.00 & -2.50 & -2.95 & -1.60 \\
\hline Sagami Rwy Co Ltd & 0.00 & 0.00 & 0.00 & 0.00 & 0.00 & 0.00 & 0.00 \\
\hline Sanyo Elec Cr Co Ltd & 0.00 & 0.00 & 0.00 & 0.00 & -2.50 & -2.50 & 0.00 \\
\hline Mitsui Sumitomo Ins Co Ltd & 8.00 & 0.00 & 0.00 & -7.67 & 1.58 & 1.92 & -0.58 \\
\hline Sompo Japan Ins Inc & 0.00 & 0.00 & 0.00 & 0.00 & 0.00 & 0.00 & 0.71 \\
\hline Takefuji Corp & -2.53 & 2.45 & -0.25 & -2.00 & -0.38 & -2.71 & -0.46 \\
\hline UFJ Bank Ltd & 1.95 & 0.23 & 0.00 & -17.55 & 0.00 & -15.36 & -1.52 \\
\hline All entities & $\begin{array}{c}1.18 \\
(0.68) \\
\end{array}$ & $\begin{array}{c}0.48 \\
(0.27) \\
\end{array}$ & $\begin{array}{l}-1.27 \\
(-0.73)\end{array}$ & $\begin{array}{c}-2.44 \\
(-1.41)\end{array}$ & $\begin{array}{l}-0.26 \\
(-0.15)\end{array}$ & $\begin{array}{l}-2.32 \\
(-0.60)\end{array}$ & $\begin{array}{l}-1.34 \\
(-0.45)\end{array}$ \\
\hline $\begin{array}{l}\text { All entities with non-zero CDS } \\
\text { spread changes on days } 0 \text { to }+4\end{array}$ & $\begin{array}{c}1.77 \\
(0.95)\end{array}$ & $\begin{array}{c}0.71 \\
(0.38)\end{array}$ & $\begin{array}{l}-1.90 \\
(-1.02)\end{array}$ & $\begin{array}{l}-3.38^{* * *} \\
(-1.81)\end{array}$ & $\begin{array}{l}-0.36 \\
(-0.19)\end{array}$ & $\begin{array}{l}-3.16 \\
(-0.75)\end{array}$ & $\begin{array}{c}0.10 \\
(0.03)\end{array}$ \\
\hline
\end{tabular}

These tables show individual and average changes in CDS spreads (expressed in basis points) on various periods around the bailout announcement date (day $0=$ May $19^{\text {th }}, 2003$ ). $t$-statistics are reported in parentheses below the average changes in CDS spreads. Significance levels for CDS spread changes are determined with reference to the standard deviation of changes estimated over a 150-day estimation window.

*** indicates statistical significance at the $1 \%$ level 